\title{
The Timing and Source of Long-Run Returns Following Repurchases
}

\author{
Leonce Bargeron, Alice Bonaime, and Shawn Thomas*
}

\begin{abstract}
This paper investigates the timing and source of anomalous positive long-run abnormal returns following repurchase authorizations. Returns between program authorization and completion announcements are indistinguishable from 0. Abnormal returns occur only after completion announcements. Long-run returns are largely attributable to announcement returns at subsequent authorizations and takeover attempts; that is, anomalous postauthorization returns are not persistent drifts but rather step functions. These findings have important implications for prior papers examining this most persistent and widespread anomaly. Further, our results serve to refocus the search for a rational explanation for the anomaly on subsequent repurchase announcements and takeover bids.
\end{abstract}

\section{Introduction}

The positive long-run abnormal stock returns following open market share repurchase (OMR) authorizations are one of the largest and most persistent anomalies documented in the finance literature. Ikenberry, Lakonishok, and Vermaelen (ILV) (1995) first report the anomaly in U.S. data, and subsequent studies (see, e.g., ILV (2000), Chan, Ikenberry, and Lee (2004), Grullon and Michaely (2004), Peyer and Vermaelen (PV) (2009), and Manconi, Peyer, and Vermaelen (2012)) confirm its existence in other countries and its persistence. However, the precise nature of the information in OMRs to which investors apparently underreact remains unclear, and the anomalous returns remain a challenge to the efficient markets hypothesis. This paper investigates the timing and source of long-run

*Bargeron, leonce.bargeron@uky.edu, Gatton College of Business \& Economics, University of Kentucky; Bonaime, alicebonaime@email.arizona.edu, Eller College of Management, University of Arizona; and Thomas (corresponding author), shthomas@katz.pitt.edu, Katz Graduate School of Business, University of Pittsburgh. We thank Matt Billett, David Denis, Diane Denis, Amy Dittmar, Jesse Ellis, Gustavo Grullon (the referee), Kristine Hankins, Jarrad Harford (the editor), Brad Jordan, Kathy Kahle, Jason Karceski, Andrew Koch, Manoj Kulchania, Yelena Larkin, Jacob Oded, Marios Panayides, Michael Ryngaert, Jared Smith, and seminar participants at the 2013 American Finance Association Meeting, the University of Kentucky, and the University of Pittsburgh for helpful comments and suggestions. Elements of this paper circulated previously under the title "Returns over the Life-Cycles of Open Market Repurchases." We also thank Di Kang, Ahmet Kurt, Tom Shofi, and Lilong Tao for research assistance. Any errors remain our own. 
returns following repurchases to isolate the specific information in authorizations to which investors underreact.

We initially construct a novel data set of 3,089 announcements that firms have completed individual repurchase programs. These data allow us to observe long-run abnormal stock returns to programs over the periods between repurchase authorization and completion. This approach is somewhat analogous to the approach used in examining post-earnings announcement drift, where, due to the known intervals between earnings announcements, the event windows are chosen so as not to include subsequent events of interest, that is, earnings announcements or, in the context of our study, subsequent OMR authorizations. We find that long-run abnormal returns are not significantly different from 0 over repurchase completion periods, that is, over the precise periods during which all information regarding a particular program is revealed. However, when we estimate long-run returns over the standard 12-, 24-, 36-, and 48-month event windows, we find strong evidence of positive long-run returns. Hence, positive and statistically significant abnormal returns are present only in the periods after individual repurchase programs end.

To be considered an anomaly, excess returns do not have to be evident immediately following some common sample event and then continue unabated. However, for a couple of reasons, it is surprising and informative that abnormal returns are not evident during the periods when repurchases are being executed. First, programs often take considerable time to complete, and large positive average returns are generally evident for even the first year after authorizations. Second, during the completion periods, noisy information on the progress of programs can be inferred from quarterly statements. If abnormal returns relate to actual repurchases of shares, then, as information on repurchasing activity is revealed, this information should affect returns. Our results indicate that it does not. Thus, the repurchase anomaly is not likely explained, for example, by investors consistently underestimating the pace or extent of actual repurchases and only slowly fully impounding the positive information content of actual repurchases into stock prices via updating based on subsequent quarterly statements.

Our investigation of the sources of the excess returns following actual repurchase event windows reconsiders the same potential sources proposed by ILV (1995), the paper that first documents the anomaly. Specifically, we consider subsequent repurchase announcements and takeover announcements. ILV (1995) conclude that these initially proposed and arguably most-plausible explanations do not account for the anomalous returns in their sample. However, we construct more powerful tests via a sample of more than 18,000 authorizations and a much longer and more complete time series of subsequent events. We find that, as illustrated in Figure 1, the positive and significant long-run excess returns documented are substantially attributable to positive and significant announcement returns at subsequent repurchase authorizations and takeover attempts. Further, as illustrated in Figure 2, the average long-run positive returns after OMR authorizations are most accurately depicted as i) discrete positive abnormal returns at the announcements of subsequent events, with insignificant returns in the periods between such announcements, and ii) abnormal returns that are indistinguishable from 0 for firms not experiencing these subsequent events. In other words, 


\section{FIGURE 1}

\section{Cumulative Alphas Excluding Months with Subsequent Events}

Figure 1 reflects long-run abnormal returns for the full sample of 18,293 repurchase authorizations. Where indicated, abnormal returns are calculated excluding firm-months during which a subsequent repurchase authorization is announced and months during which a takeover attempt is announced. Monthly abnormal returns $(\alpha)$ are estimated from FamaFrench (1993) 3-factor calendar-time portfolio regressions: $R_{t}-R_{f, t}=\alpha_{1}+\beta_{1}\left(R_{m_{k t}, t}-R_{f, t}\right)+\beta_{2} S M B_{t}+\beta_{3} H M L_{t}$, where $R_{t}$ is the return on an equal-weighted portfolio of stocks at time $t$. $R_{f, t}$ and $R_{m k t, t}$ are the risk-free rate and the return of the market at time $t . S M B_{t}$ and $H M L_{t}$ are the monthly returns on the Fama-French size and book-to-market factors in month $t$. The intercept term $(\alpha)$ of the regression represents the average monthly excess return in the event period. Cumulative alphas are calculated as the monthly excess return times the number of months since the authorization.

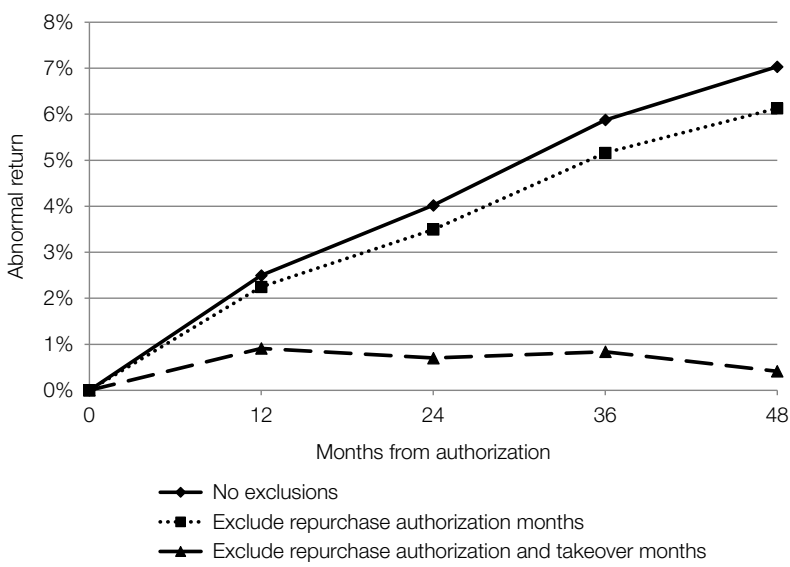

FIGURE 2

Source of Post-OMR Authorization Long-Run Abnormal Returns

Figure 2 shows hypothetical long-run returns series for a firm with no subsequent repurchase or takeover attempt announcement, a firm with 3 consecutive repurchase authorizations, and a firm with a takeover attempt announcement.

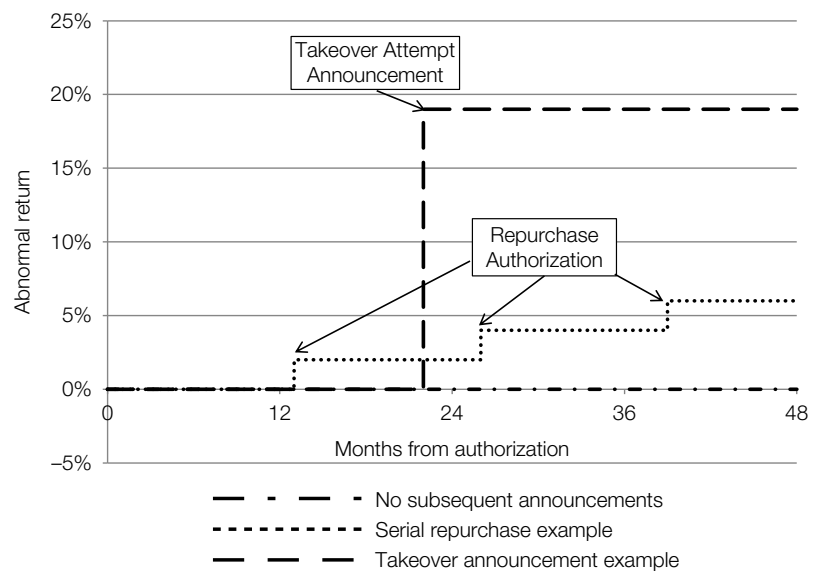


post-OMR abnormal returns are step functions not gradual persistent drifts. These findings are robust to the choice of subsamples (including value firms), the approach used to isolate the effects of subsequent events, and the basic methodology used to calculate long-run excess returns.

While investors clearly do not know at the time of authorizations whether a firm will conduct a subsequent repurchase or be the subject of a future takeover attempt, the observed association between subsequent takeover attempts and repurchase authorizations and returns is consistent with investors underreacting to the increased probabilities of these events. Given that our primary purpose is to determine the source of observed returns and not to devise an implementable trading strategy, conditioning on ex post information is not problematic.

This paper contributes to the literature by improving our understanding of the timing and source of the seemingly anomalous positive long-run post-OMR returns. To the best of our knowledge, no prior paper has systematically investigated returns over event windows corresponding to actual repurchase periods for U.S. firms and isolated the exact timing of the abnormal returns within the standard event windows. Also, it seems clear from our results that if the abnormal returns following repurchases reflect underreaction on the part of investors, then the underreaction is related to changes in the expected returns from subsequent OMR authorizations and takeover attempts. There are a number of papers since ILV (1995) that document positive abnormal returns following authorizations and offer explanations for the returns; however, these papers do not investigate the influence of subsequent repurchase announcements and actual takeover attempts despite the intuitive appeal of such potential explanations and their prominence among the explanations considered in the paper that started this literature. Most recently, Lin, Stephens, and Wu (2014) propose takeover risk as an explanation for the observed positive abnormal returns, but the risk exposures and the return patterns we document are inconsistent with a straightforward takeover-risk explanation. Below, we discuss the implications of our findings for the conclusions reached in Lin et al. (2014) and other papers. Also, our findings refocus the search for a rational explanation for the anomaly back on the sources first proposed.

This paper proceeds as follows: In Section II, we describe the prior related literature. In Section III, we describe our sample construction and provide summary statistics. In Section IV, we report analyses of the timing and source of long-run excess returns. Section V concludes.

\section{Related Literature}

ILV (2000) investigate the timing of post-OMR abnormal returns in Canada. Canadian firms must get approval to repurchase from the exchanges where the firms' shares trade; if authorized, programs last 1 year, and firms are required to report monthly the shares repurchased. ILV (2000) find abnormal performance of $0.59 \%$ per month over the 3 years after the approval. Firms actively repurchasing shares experience only modest returns while the programs are in effect but exhibit large positive subsequent returns. However, subsequent repurchases or takeovers are not examined as explanations for the observed returns. As acknowledged in ILV (2000), there are substantial differences between their setting and the United 
States in terms of the fraction of firms undertaking repurchases and the volume of repurchase (e.g., less than 5\% of Canadian firms complete their programs). Thus, while clearly informative, there are obvious caveats to generalizing these results to a large sample of U.S. firms.

To varying degrees, Chan et al. (2004), Grullon and Michaely (2004), and PV (2009) investigate potential sources of post-OMR abnormal returns. Chan et al. (2004) find consistently positive average abnormal returns to quarterly earnings announcements in the second, third, and fourth years following OMRs. The authors interpret this as evidence of an incomplete initial market reaction to the information in repurchases regarding future earnings. However, the sum of average abnormal returns to the first eight quarters of earnings announcements after the repurchase announcement explains only 143 basis points of the 1,097-basis-point 2-year buy-and-hold return following the OMRs. Chan et al. (2004) attribute the remainder to "real, unanticipated information" revealed subsequent to repurchase announcements. Our results suggest that this unanticipated information regards subsequent repurchases or takeovers.

Grullon and Michaely (2004) conclude that investors fail to fully anticipate reductions in firms' systematic risk and cost of capital following repurchases motivated by declines in growth prospects. Grullon and Michaely (2004) do not examine subsequent repurchases or takeovers. However, if subsequent takeovers and authorizations are more likely for firms with greater reductions in systematic risk, then our results are potentially consistent. Nonetheless, it remains unclear why the underreaction is not apparent until after firms actually complete repurchases.

PV (2009) favor an "analyst mistake" explanation for the anomaly under which analysts are overly pessimistic in their recommendations after disappointing earnings. Overly pessimistic analyst recommendations lead to undervaluation, which prompts firms to repurchase but persists for long periods due to analysts' reluctance to admit their mistakes by revising their recommendations upward. This explanation assumes the benefits of stubbornness to the analysts outweigh the reputational costs, such as lower rankings by analyst ranking services due to poor earnings forecast accuracy. If such analyst behavior increases the likelihood that a repurchasing firm will conduct subsequent repurchases or become the target of a takeover bid, then our results are potentially consistent with PV (2009). Nonetheless, it remains unclear why the market begins to reverse analysts' mistakes only after firms fully complete repurchases.

Lin et al. (2014) investigate takeover risk as the source of the repurchase anomaly. Firms subject to greater likelihood of takeover face larger fluctuations in value across takeover waves. As waves are tied to economic fundamentals, exposure to such fluctuations is a systematic risk. Lin et al. (2014) hypothesize that repurchasing firms are more exposed to takeovers and post-OMR abnormal returns are due to increased takeover risk. They find that abnormal returns are insignificant when the Cremers, Nair, and John (CNJ) (2009) takeover risk factor is included in the model of expected returns. We confirm this result; however, we also provide additional evidence that takeover risk is not a straightforward explanation for the repurchase anomaly, despite our finding that excess returns are substantially attributable to actual subsequent takeover attempts. Specifically, estimated takeover factor betas reveal that the subsample of firms without a 
subsequent takeover or repurchase announcement has significantly greater exposure to takeover risk; that is, the subsample of firms with greater exposure to takeover risk does not exhibit significant abnormal returns, whereas the subsample of firms with less exposure does. Also, our finding that excess returns are step functions is inconsistent with abnormal returns steadily accruing over postOMR periods due to increased takeover risk. Lin et al. (2014) do not investigate the specific timing of abnormal returns or the influence of subsequent repurchase authorizations.

\section{Sample Formation and Descriptive Statistics}

We search Factiva.com over the period Jan. 1, 1980-Sept. 30, 2010 for announcements by firms that they have completed OMRs. Appendix A details the search terms and provides examples of completion announcements. We collect details regarding the date, purchases under the plan, etc. We match each completion announcement with the authorization referenced in the announcement, if any, or with the OMR authorization by the same firm that immediately precedes the completion announcement. Our sample of OMR authorizations is obtained primarily from the Thomson Financial's Securities Data Company (SDC) database on Mergers and Acquisitions but also includes authorizations identified via a search of Factiva. ${ }^{1}$

Panel A of Table 1 reports the frequency distribution of OMR authorization and completion announcements by year. The sample of authorizations includes 19,498 OMRs announced by 7,437 unique firms between Jan. 1, 1979 and Sept. 30, 2010. The volume of completions generally tracks authorization activity but, not surprisingly, with a lag. While 3,089 completion announcements by 1,712 unique firms may appear small relative to nearly 19,500 authorizations, only programs in which all of the authorized shares are actually repurchased could have completion announcements. For the 14,710 authorizations by firms with the necessary data to estimate actual share repurchases, we infer that 8,091 complete their programs within 3 years. Of these, over 1 quarter, 2,044, announce the completion. ${ }^{2}$ The last two columns of Panel A disaggregate completion announcements by whether the completion is announced concurrently with a new OMR authorization. Completions are split approximately equally between the two types.

Panel B of Table 1 reports the frequency distribution of the number of authorization and completion announcements per firm. The average (median) firm

\footnotetext{
${ }^{1}$ If we are unable to match program completion announcements with authorizations from SDC, then we search Factiva.com for the corresponding authorization. Of the 19,498 authorizations in our sample, 1,175 (6.03\%) are collected from Factiva.com. In some cases, this results in identifying authorizations that occurred before 1980 .

${ }^{2}$ We use quarterly statements of cash flow data obtained from Compustat, as in Stephens and Weisbach (1998) and Banyi, Dyl, and Kahle (2008). Indicative of the noise involved in estimating actual repurchases, we find that a completion announcement was made within 3 years of an authorization in 282 cases for which we infer that the authorization was not completed within 3 years. While quarterly statements of cash flow are not available for firms on Bank Compustat, we note that one-third of our sample of completion announcements are made by banks (based on the Fama-French 48 industry classification codes), which, given a total number of authorizations by these firms of 3,855, suggests that financial firms may be more likely to complete programs and announce completions.
} 
TABLE 1

Summary Statistics

Table 1 presents summary statistics on open market repurchase authorizations and completions. Completions are also separated into completions without a concurrent new authorization announcement and completions with a concurrent new authorization announcement. Authorizations are from Thomson Financial Securities Data Company (SDC) Mergers and Acquisitions Database; subsequent completion announcements are from Factiva. If SDC does not include an authorization that corresponds to a completion announcement, then we search Factiva for the authorization. Panel A presents the frequency of authorizations and completions by year. Panel B summarizes the number of completion announcements by firm. Panel C presents summary statistics on the number of calendar days between authorizations and completions.

Panel A. Frequency of OMR Authorizations and Completions by Year

\begin{tabular}{|c|c|c|c|c|}
\hline Year & Authorization & Completion & $\begin{array}{c}\text { Completion } \\
\text { without Concurrent } \\
\text { New Authorization }\end{array}$ & $\begin{array}{c}\text { Completion with } \\
\text { Concurrent New } \\
\text { Authorization } \\
\end{array}$ \\
\hline 1979 & 6 & 0 & 0 & 0 \\
\hline 1980 & 2 & 10 & 9 & 1 \\
\hline 1981 & 10 & 1 & 0 & 1 \\
\hline 1982 & 12 & 11 & 10 & 1 \\
\hline 1983 & 10 & 4 & 2 & 2 \\
\hline 1984 & 28 & 16 & 12 & 4 \\
\hline 1985 & 141 & 13 & 9 & 4 \\
\hline 1986 & 198 & 24 & 14 & 10 \\
\hline 1987 & 844 & 28 & 14 & 14 \\
\hline 1988 & 278 & 44 & 19 & 25 \\
\hline 1989 & 506 & 42 & 18 & 24 \\
\hline 1990 & 861 & 61 & 20 & 41 \\
\hline 1991 & 315 & 23 & 15 & 8 \\
\hline 1992 & 491 & 28 & 14 & 14 \\
\hline 1993 & 497 & 46 & 36 & 10 \\
\hline 1994 & 894 & 58 & 34 & 24 \\
\hline 1995 & 990 & 31 & 24 & 7 \\
\hline 1996 & 1,365 & 85 & 59 & 26 \\
\hline 1997 & 1,182 & 140 & 84 & 56 \\
\hline 1998 & 1,940 & 314 & 137 & 177 \\
\hline 1999 & 1,520 & 369 & 176 & 193 \\
\hline 2000 & 905 & 341 & 154 & 187 \\
\hline 2001 & 706 & 209 & 89 & 120 \\
\hline 2002 & 496 & 158 & 67 & 91 \\
\hline 2003 & 471 & 140 & 69 & 71 \\
\hline 2004 & 566 & 116 & 50 & 66 \\
\hline 2005 & 700 & 150 & 62 & 88 \\
\hline 2006 & 672 & 180 & 90 & 90 \\
\hline 2007 & 1,001 & 218 & 112 & 106 \\
\hline 2008 & 1,087 & 149 & 85 & 64 \\
\hline 2009 & 424 & 38 & 22 & 16 \\
\hline 2010 & 380 & 42 & 17 & 25 \\
\hline All & 19,498 & 3,089 & 1,523 & 1,566 \\
\hline
\end{tabular}

Panel B. Frequency of OMR Authorizations and Completions by Firm

\begin{tabular}{|c|c|c|c|c|c|c|c|c|c|c|c|c|c|}
\hline Announcement Type & 1 & 2 & 3 & 4 & 5 & 6 & 7 & 8 & 9 & 10 & 11-15 & $\underline{16-20}$ & $21-25$ \\
\hline Authorization & 3,336 & 1,580 & 874 & 484 & 349 & 239 & 180 & 125 & 84 & 67 & 103 & 10 & 6 \\
\hline Completion & 1,101 & 324 & 113 & 61 & 38 & 25 & 21 & 14 & 7 & 4 & 3 & 1 & \\
\hline $\begin{array}{l}\text { Completion without } \\
\text { concurrent new } \\
\text { authorization }\end{array}$ & 726 & 167 & 51 & 30 & 10 & 10 & 5 & 2 & 2 & 0 & 1 & & \\
\hline $\begin{array}{l}\text { Completion with } \\
\text { concurrent new } \\
\text { authorization }\end{array}$ & 694 & 169 & 61 & 36 & 12 & 8 & 4 & 6 & 1 & 0 & 1 & & \\
\hline
\end{tabular}

$\underline{\text { Panel C. Calendar Days between OMR Authorizations and Completions }}$

\begin{tabular}{|c|c|c|c|c|c|c|c|c|}
\hline \multirow[b]{2}{*}{ Announcement } & \multirow[b]{2}{*}{$N$} & \multirow[b]{2}{*}{ Mean } & \multirow[b]{2}{*}{ Min. } & \multicolumn{3}{|c|}{ Percentiles } & \multirow[b]{2}{*}{ Max. } & \multirow{2}{*}{$\begin{array}{r}\% \text { Announced } \\
\text { within } 365 \text { Days }\end{array}$} \\
\hline & & & & 25th & 50th & 75th & & \\
\hline Completion & 2,948 & 327.6 & 1 & 112 & 223 & 405 & 4,046 & $70.15 \%$ \\
\hline $\begin{array}{l}\text { Completion without } \\
\text { concurrent new } \\
\text { authorization }\end{array}$ & 1,433 & 266.2 & 1 & 83 & 181 & 341 & 4,046 & $77.74 \%$ \\
\hline $\begin{array}{l}\text { Completion with } \\
\text { concurrent new } \\
\text { authorization }\end{array}$ & 1,515 & 385.7 & 1 & 149 & 279 & 476 & 3,353 & $62.97 \%$ \\
\hline
\end{tabular}


announced 2.62 (2.00) authorizations over the roughly 30-year sample period; however, a number of firms conducted OMRs on a regular basis. For example, 1,163 firms announced 5 or more authorizations during the sample period, and the maximum number of authorizations by a particular firm is 25 . The average (median) number of completion announcements among firms that made such announcements is 1.80 (1.00). There are several other items important for our analysis that are not readily apparent from Panel B. For instance, nearly $25 \%$ of authorizations in the sample are followed by a subsequent authorization by the same firm within 1 year, and nearly half of the authorizations are followed by a subsequent authorization within 3 years. Also, authorizations by frequent initiators, defined as firms that have announced at least 2 authorizations in the previous 5 years, increase from $9 \%$ of authorizations in the 1980 s, to $29 \%$ of authorizations in the 1990s and then again to $34 \%$ of authorizations in the 2000s. Further, we find many firms' authorizations occur in uninterrupted sequences. For instance, we identify 233 sequences where firms announce without interruption: an authorization, completion of the initial authorization with a concurrent new authorization, and completion of the second authorization with a concurrent new third authorization. We also observe 1 sequence of 10 such uninterrupted sequences.

Panel $\mathrm{C}$ of Table 1 reports summary statistics regarding the number of calendar days between an authorization and a completion. Slightly more than $70 \%$ of all completions are announced within 365 days of the authorization announcement. Nearly $78 \%$ of completion announcements without a new authorization are made within 365 days, whereas close to $63 \%$ of completion announcements with a new authorization are made within 365 days. $^{3}$

An important takeaway from Panels B and C of Table 1 is that many actual repurchase windows are shorter in duration that even the shortest standard event window (i.e., 1 calendar year). Further, the average standard event window will include more than 1 repurchase related announcement, that is, subsequent authorizations, and the number of such announcements increases with the length of the window.

\section{Long-Run Returns: Timing and Source}

\section{A. Timing: Long-Run Returns over Actual Repurchase Event Windows}

To facilitate comparability of our results with both older and more recent prior literature (e.g., ILV (1995) and PV (2009)), we estimate long-run excess returns using the Fama and French (1993) calendar-time portfolio approach, accounting for risk factors associated with overall market movements, firm size, and book-to-market ratios. By equally weighting each time period as opposed to each repurchase announcement event, the calendar-time portfolio approach accounts for any time clustering (see, e.g., Fama (1998) and Mitchell and Stafford (2000)).

\footnotetext{
${ }^{3}$ In additional unreported tests, we compare the percentage of shares sought in authorizations that are subsequently completed without a concurrent new authorization announcement to the percentage of shares sought in authorizations that are subsequently completed with a concurrent authorization. The mean percentage of shares sought does not differ significantly between the groups. This suggests that "serial" repurchasers do not merely divvy up average sized programs into multiple smaller authorizations.
} 
We estimate average monthly abnormal returns using the following regression:

$$
R_{t}-R_{f, t}=\alpha_{1}+\beta_{1}\left(R_{m k t, t}-R_{f, t}\right)+\beta_{2} S M B_{t}+\beta_{3} H M L_{t},
$$

where $R_{t}$ is the return on an equal-weighted portfolio of stocks at time $t$, and where month $t$ falls between the month of the authorization announcement and the actual month of the completion announcement or some specified number of months following the authorization (i.e., 12, 24, 36, or 48 months). ${ }^{4} R_{f, t}$ and $R_{m k t, t}$ are the risk-free rate and the return of the market at time $t . S M B_{t}$ and $H M L_{t}$ are the monthly returns on the Fama-French size and book-to-market factors in month $t .^{5}$ The intercept term $(\alpha)$ represents the average monthly excess return in the event period. $^{6}$

Panel A of Table 2 presents the results of average monthly abnormal returns regressions from the month following the authorization until completion. When we do not include the months of the completion announcement in the return calculation, monthly abnormal returns are $0.16 \%$ per month and not statistically different from 0 . We also report abnormal returns when, respectively, all completion months are included, only months of completion announcements without concurrent new authorizations are included, and only months of completion announcements with concurrent new authorizations are included. Bargeron, Bonaime, and Thomas (2016) document positive average abnormal returns to completion announcements accompanied by new authorizations and negative average abnormal returns to completion announcements not accompanied by new authorizations. Thus, including the month of the completion announcements will influence the observed long-run abnormal returns. Indeed, the average monthly excess return when the months of completion are included is $0.13 \%$ if the completions are not concurrent with a new authorization but $0.20 \%$ if they are. Excess returns are not statistically significant in either case. We further explore the effect of the completion month in Panel B of Table 2 for the subsample of OMR programs with completion announcements that are concurrent with new authorizations. The inclusion of completion months with concurrent new authorizations causes average abnormal monthly returns to jump from $0.19 \%$ per month to $0.31 \%$ per month, with the latter significant at the $5 \%$ level.

\footnotetext{
${ }^{4}$ To be consistent with the prior literature, we equally weight the stocks in the portfolios, as in PV (2009). PV (2009) also note that weighting firms equally yields greater power to identify abnormal returns than value weighting. Therefore, equal weighting makes it more difficult to find a result of insignificant abnormal returns.

${ }^{5}$ Details regarding construction procedures and data for SMB and HML factors are available from Kenneth French's Web site (http://mba.tuck.dartmouth.edu/pages/faculty/ken.french/data_library .html).

${ }^{6}$ We choose calendar-time portfolios over the Ibbotson (1975) returns across time and securities (IRATS) approach, since we have varying event windows. In other words, given that firms drop out of the calendar-time portfolio after completion announcements and that the amount of time between authorization and completion varies by firm, each "event" (i.e., OMR program) is associated with its own unique event window. However, when we verify the robustness of our results to the IRATS approach, we find that, for the sample of repurchase authorizations with completion announcements, cumulative abnormal returns are again not statistically different from $0:-0.16 \%$ ( $t$-statistic $=-0.16)$ over 12 months and $2.74 \%(t$-statistic $=1.12)$ over 24 months. Longer time windows are largely uninformative given that over $90 \%$ of completions are announced within 24 months.
} 
TABLE 2

Long-Run Abnormal Returns from OMR Authorization to Completion Announcements

Table 2 presents long-run abnormal returns for our sample of repurchase authorizations with subsequent completion announcements. Monthly abnormal returns $(\alpha)$ are estimated from Fama-French (1993) 3-factor calendar-time portfolio regressions: $R_{t}-R_{t, t}=\alpha_{1}+\beta_{1}\left(R_{m k t, t}-R_{f, t}\right)+\beta_{2} S M B_{t}+\beta_{3} H M L_{t}$, where $R_{t}$ is the return on an equal-weighted portfolio of stocks at time $t$. $R_{f, t}$ and $R_{m k t}$ are the risk-free rate and the return of the market at time $t . S M B_{t}$ and $H M L_{t}$ are the monthly returns on the Fama-French size and book-to-market factors in month $t$. The intercept term $(\alpha)$ of the regression represents the average monthly excess return in the event period. We measure returns from the month after the authorization announcement until the month of completion, exclusive or inclusive, as indicated. Panel A presents results for the sample of 2,861 repurchase authorizations with subsequent completion announcements and monthly returns data from the Center for Research in Security Prices (CRSP). Panel B presents results for the subsample of 1,484 repurchase authorizations with completion announcements that are made concurrent with new authorizations and with monthly returns data from CRSP. $t$-statistics are reported in square brackets. ${ }^{*},{ }^{* *}$, and ${ }^{* * *}$ indicate significance at the $10 \%, 5 \%$, and $1 \%$ levels, respectively.

Treatment of Completion Announcement Month

Panel A. Authorizations with Completion Announcements

Excluding completion announcement month

Including completion announcement month

Including completion announcement month only if no new authorization

Including completion announcement month only if new authorization

Panel B. Authorizations with Completion Announcements and Concurrent New Authorizations

It is interesting that we do not observe significant returns over the period between initiation and completion. If abnormal returns relate to actual repurchases of shares, then, as information on firms' repurchasing activity is revealed, we would expect this information to affect returns. Given the average time to completion is 328 days, investors would generally be provided with approximately 3 quarterly statements from which to infer actual repurchases. Also, in sharp contrast to prior papers documenting positive long-run drift after OMR authorizations for standard event windows, we observe reliably positive excess returns over the actual repurchase event windows of completed programs only when we deliberately restrict our sample to completions with concurrent new authorizations and include the positive average announcement returns attendant with information regarding subsequent repurchase programs. ${ }^{7}$

\section{B. Timing: Long-Run Returns over Standard Event Windows and Postcompletion Windows}

One potential concern with the results in Table 2 is that this sample is somehow systematically different from those of prior papers. Our sample of OMRs with completion announcements contains nearly 3,100 programs. Given ILV (1995) examine a sample of 1,239 OMRs and PV (2009) examine a sample of

\footnotetext{
${ }^{7}$ Results reported in Table 2 are similar in nature when abnormal returns are estimated using a 4-factor model that includes the momentum factor of Carhart (1997). Specifically, we observe positive and significant abnormal returns only when completion months are included and completion months with concurrent new authorizations entirely account for the significant positive returns.
} 
3,481 OMRs, sample size alone is unlikely to account for the lack of abnormal returns in the sample of OMRs with completions. Further, as reported in Panel A of Table 3, average monthly excess returns for this subsample over the standard event windows range from $0.23 \%$ to $0.32 \%$ and are statistically different from 0 at the $5 \%$ level in all cases. As will be evident from subsequent tables, the abnormal returns for the completion subsample are actually larger than those for the universe of authorizations. Hence, the observed long-run abnormal returns over the standard windows for our sample of OMRs with completion announcements are entirely consistent with prior literature.

The observed differences in excess returns over the actual repurchase event windows and the standard windows suggest that large positive abnormal returns are present in the periods following completions. We calculate the average monthly excess returns during the postcompletion announcement period (i.e., from the month after the completion announcement until 12, 24, 36, or 48 months after the authorization). As reported in Panel A of Table 3, the average monthly excess returns during the postcompletion period range from $0.67 \%$ $(t$-statistic $=3.72)$ from completion to 12 months post-authorization to $0.28 \%$

\section{TABLE 3}

Long-Run Abnormal Returns over Standard Windows for OMR Authorizations with Completion Announcements

Table 3 presents long-run returns for the sample of 2,861 OMR programs associated with subsequent completion announcements and with monthly returns data from the Center for Research in Security Prices (CRSP). Panel A presents abnormal returns over standard 12-, 24-, 36-, and 48-month windows beginning the month after the authorization announcement and during the postcompletion period, that is, from the month after the completion announcement until $12,24,36$, or 48 months after the authorization. Panel B presents subsample analysis over standard windows; subsamples are created on the basis of whether a subsequent repurchase or takeover announcement was made during the corresponding returns calculation period. Monthly abnormal returns $(\alpha)$ are estimated from Fama-French (1993) 3-factor calendar-time portfolio regressions: $R_{t}-R_{f, t}=\alpha_{1}+\beta_{1}\left(R_{m k t, t}-R_{f, t}\right)+\beta_{2} S M B_{t}+\beta_{3} H M L_{t}$, where $R_{t}$ is the return on an equal-weighted portfolio of stocks at time $t . R_{t, t}$ and $R_{m k t, t}$ are the risk-free rate and the return of the market at time $t$. SMB ${ }_{t}$ and $H M L_{t}$ are the monthly returns on the Fama-French size and book-to-market factors in month $t$. The intercept term $(\alpha)$ of the regression represents the average monthly excess return in the event period. $t$-statistics are reported in square brackets with the number of repurchase programs reported below the $t$-statistics. ${ }^{\star},{ }^{* *}$, and ${ }^{* * *}$ indicate significance at the $10 \%, 5 \%$, and $1 \%$ levels, respectively.

\section{Months}

24 Months

36 Months

$0.2713^{* *}$

[2.465]

$0.3518^{\text {*** }}$

[2.914]

[2.384]

$0.6682^{\star \star \star}$

$0.5494^{\star * *}$

[4.230]

48 Months

Panel A. $\alpha$ for Authorizations with Completion Announcements

Full window

Postcompletion period only

Panel B. $\alpha$ for Subsamples of Authorizations with Completion Announcements

(1) Repurchase authorizations with no
subsequent repurchase authorizations
(2) Repurchase authorizations with
subsequent repurchase authorizations
Difference (1)-(2)
(3) Repurchase authorizations with no
subsequent repurchase authorizations or
takeover announcements
(4) Repurchase programs with subsequent
repurchase authorizations or takeover
announcements
Difference (3) - (4)

$0.2704^{\star}$
$[1.911]$
1,501
$0.5461^{\star \star \star}$
$[2.951]$
1,433
-0.2757
$[-1.194]$
0.1805
$[1.240]$
1,438
$0.6121^{\star \star \star}$
$[3.440]$
1,496
$-0.4316^{\star}$
$[-1.883]$

0.1479

[1.136]

951

$0.4852^{\star \star \star}$

[3.661]

$\begin{array}{r}1,986 \\ \hline\end{array}$

$-0.3372^{*}$

-0.3372
$[-1.815]$

0.0022

[0.017]

814

0.5374
$[4.133]$

2,123

$-0.5351^{\star \star *}$

\begin{tabular}{|c|c|}
\hline $\begin{array}{c}0.1562 \\
{[1.141]} \\
758\end{array}$ & $\begin{array}{c}-0.0163 \\
{[-0.121]} \\
669\end{array}$ \\
\hline $\begin{array}{c}0.4412^{\text {** }} \\
{[3.751]} \\
2,180\end{array}$ & $\begin{array}{c}0.4209^{\star \star \star \star} \\
{[3.752]} \\
2,269\end{array}$ \\
\hline $\begin{array}{l}-0.2850 \\
{[-1.569]}\end{array}$ & $\begin{array}{l}-0.4372^{\star \star} \\
{[-2.478]}\end{array}$ \\
\hline $\begin{array}{c}0.0267 \\
{[0.189]} \\
594\end{array}$ & $\begin{array}{c}-0.0840 \\
{[-0.580]} \\
480\end{array}$ \\
\hline $\begin{array}{l}0.4681^{* * *} \\
{[3.923]} \\
2,344\end{array}$ & $\begin{array}{c}0.4124^{\star \star \star} \\
{[3.664]} \\
2,458\end{array}$ \\
\hline $\begin{array}{l}-0.4413^{\star *} \\
{[-2.368]}\end{array}$ & $\begin{array}{l}-0.4964^{\star \star \star} \\
{[-2.716]}\end{array}$ \\
\hline
\end{tabular}

$0.2288^{\text {** }}$

[2.148]

$0.2849^{\star \star}$

[2.485]

[-2.852] 
$(t$-statistic $=2.49)$ from completion to 48 months post-authorization. Further, the (unreported) difference in abnormal returns calculated over the pre- versus postcompletion time windows is negative and significant at the $5 \%$ level over the 12 month and 24-month windows (longer time windows are largely uninformative given that over $90 \%$ of completions are announced within 24 months). Thus, it is clear that the significant average abnormal returns over the standard windows are driven by returns in the months after the OMR programs have been completed.

\section{Sources: Subsequent Repurchases and Takeover Attempts}

Taken together, our initial long-run return findings regarding timing prompt an obvious question: What is the source of the excess returns in the periods after program completions? ILV (1995), in their original post-OMR long-run drift paper, propose multiple repurchase announcements as meriting investigation. As previously noted, nearly a quarter of authorizations in our sample are followed by a subsequent authorization within 1 year and nearly half of all authorizations are followed by a subsequent authorization within 3 years. Thus, the standard longrun event windows often include subsequent OMR authorizations. We also know that OMR authorizations are associated with positive and significant average announcement returns (see, e.g., Vermaelen (1981) or Comment and Jarrell (1991)). Thus, we investigate the extent to which postcompletion excess returns reflect the inclusion of subsequent OMR program announcements.

In Panel B of Table 3, we segment our OMR programs with completion announcements into two groups: those with no subsequent OMR authorizations during the event window and those with 1 or more subsequent OMR authorizations during the event window. For the subsample of OMR programs with no subsequent authorizations, we find that returns are $0.27 \%(t$-statistic $=1.91)$ using the 12-month window but much smaller in magnitude and not statistically different from 0 for all other event windows. In contrast, average monthly excess returns for the subsample of OMR programs with subsequent OMR authorizations in the event windows range from $0.42 \%$ to $0.55 \%$ and are statistically significant at the $1 \%$ level in all cases. Further, the difference in returns between the two subsamples is economically meaningful (between $0.28 \%$ and $0.44 \%$ per month) and statistically significant in the 24- and 48-month windows. These results are surprising, perhaps, given that we might expect a subsequent repurchase announcement to be more likely when managers continue to view their company's shares as undervalued, in which case excess returns should be higher for OMR programs without subsequent announcements. ${ }^{8}$ In sum, the long-run abnormal returns over standard windows are concentrated in the subsample of firms with subsequent authorization announcements.

ILV (1995) also raise the possibility that takeover-related announcements and returns may help explain the repurchase anomaly. The extant literature documents a relation between takeovers and repurchases (see, e.g., Bagwell and Shoven (1989) and Billett and Xue (2007)), and also documents that including or

\footnotetext{
${ }^{8}$ ILV ((1995), p. 206) state that "If the market underreacts to the first announcement, managers with strong conviction that their shares remain undervalued may choose to make additional announcements."
} 
excluding takeover targets from samples affects observed long-run returns in certain contexts (see, e.g., Mulherin and Poulsen (1998) regarding proxy fights and Cusatis, Miles, and Woolridge (1993) regarding spin-offs). Mulherin and Poulsen ((1998), p. 309) warn that "As a whole, the interaction of takeovers with other corporate events suggests that care must be taken by researchers who wish to study both equity and accounting performance surrounding the event." During our sample period, we find the yearly frequency of being the target of a takeover announcement is over $35 \%$ higher and significantly different for firms with an OMR authorization within the prior 3 years $(6.5 \%)$ than firms without an authorization within the prior 3 years $(4.7 \%)$. Thus, we also investigate the influence of takeover announcements on long-run returns to OMR programs. Takeover announcements are obtained from SDC and include all instances in which an OMR firm is the target of an acquisition attempt. ${ }^{9}$

Rows 3 and 4 of Panel B in Table 3 report long-run abnormal returns for our sample of programs with completion announcements broken into subsamples of those with no subsequent OMR authorization or takeover announcements during the event window and those with one or more subsequent announcements during the event window. For the subsample of programs with no subsequent announcements, average monthly excess returns are not statistically different from 0 over any standard window. In contrast, average monthly excess returns for the subsample of OMR programs with subsequent announcements are large (between $0.41 \%$ and $0.61 \%$ per month) and consistently statistically significant at the $1 \%$ level. Further, the differences in returns between the two subsamples range from $0.43 \%$ to $0.54 \%$ per month and are statistically significant during all four time periods.

As mentioned above, ILV (1995) also consider the possibility that abnormal performance results from multiple repurchase announcements or takeover activity. ILV (1995) show that the abnormal performance found in their sample is robust to including only firms that have not made a prior repurchase announcement for 3 years. However, this approach is backward looking, while our approach is forward looking. Our approach effectively excludes subsequent authorization announcements during the event windows. With regard to takeover announcements, ILV (1995) calculate abnormal performance using only the subsample of repurchasing firms that survive for at least 4 years following the repurchase announcements and find that 3-year compounded abnormal performance is lower in this subsample than in the full sample, but it remains significant. Firms may fail to survive for reasons other than takeovers (e.g., bankruptcies), and not all firms that are the targets of takeovers fail to survive. Thus, our approach to takeovers differs from that of ILV (1995), because we specifically identify takeover targets and account for the actual timing of the takeover attempts. Our results indicate that the previously documented positive long-run abnormal returns after OMR program authorizations are not present during the repurchase event windows and are, in large part, driven by subsequent value-increasing events (i.e., new OMR authorizations and takeover announcements).

\footnotetext{
${ }^{9}$ We do not include recapitalizations, self-tenders, exchange offers, minority stake purchases, or acquisitions of remaining interest as acquisition attempts.
} 


\section{Robustness and Additional Results}

The results reported in Tables 2 and 3 pertain to our sample of OMRs with completion announcements. Clearly, these are instances where firms' managers voluntarily update outsiders on the status of the programs. We also conduct a large sample test of our general findings that the positive long-run post-OMR authorization returns are, in large part, attributable to subsequent OMR authorizations and takeover announcements. While we cannot examine excess returns over the completion windows of programs without completion announcements, we can assess the impact of subsequent authorizations and takeovers over the standard windows for a large sample of OMR authorizations announced between Jan. 1, 1979 and Sept. 30, 2010.

As reported in Panel A of Table 4, we document positive and significant excess returns for our full sample of OMR programs over each of the respective postOMR authorization windows. Average monthly excess returns following OMR programs range from $0.21 \%$ to $0.15 \%$ and are significant at the $10 \%$ level in all cases. In Panel B of Table 4 and in Figure 3, we report returns to subsamples with and without subsequent repurchase or takeover announcements. Again, we find that positive abnormal returns are concentrated nearly exclusively in the group of OMR programs with repurchase or takeover announcements during the event

\section{TABLE 4}

\section{Long-Run Abnormal Returns over Standard Windows for all OMR Authorizations}

Table 4 presents long-run returns for the sample of 18,293 OMR program authorization announcements with monthly returns data from the Center for Research in Security Prices (CRSP). Panel A presents abnormal returns over standard 12-, 24-, 36-, and 48-month windows beginning the month after the authorization announcement. Panel B presents subsample analysis over standard windows; subsamples are created on the basis of whether a subsequent repurchase or takeover announcement was made during the corresponding returns calculation period. Monthly abnormal returns $(\alpha)$ are estimated from Fama-French (1993) 3 -factor calendar-time portfolio regressions: $R_{t}-R_{f, t}=\alpha_{1}+\beta_{1}\left(R_{m k t, t}-R_{f, t}\right)+$ $\beta_{2} S M B_{t}+\beta_{3} H M L_{t}$, where $R_{t}$ is the return on an equal-weighted portfolio of stocks at time $t$. $R_{t, t}$ and $R_{m k t, t}$ are the riskfree rate and the return of the market at time $t . S M B_{t}$ and $H M L_{t}$ are the monthly returns on the Fama-French size and book-to-market factors in month $t$. The intercept term $(\alpha)$ of the regression represents the average monthly excess return in the event period. $t$-statistics are reported in square brackets with the number of repurchase programs reported below the $t$-statistics. ${ }^{\star},{ }^{* *}$, and ${ }^{* * *}$ indicate significance at the $10 \%, 5 \%$, and $1 \%$ levels, respectively.

\begin{tabular}{|c|c|c|c|c|}
\hline \multirow{2}{*}{\multicolumn{5}{|c|}{ Panel A. $\alpha$ for All Authorizations }} \\
\hline & & & & \\
\hline All authorizations & $\begin{array}{l}0.2082^{*} \\
{[1.942]}\end{array}$ & $\begin{array}{l}0.1675^{\star} \\
{[1.879]}\end{array}$ & $\begin{array}{c}0.1632^{*} \\
{[1.955]}\end{array}$ & $\begin{array}{l}0.1465^{\star} \\
{[1.789]}\end{array}$ \\
\hline \multicolumn{5}{|l|}{ Panel B. $\alpha$ for Subsamples of All Authorizations } \\
\hline $\begin{array}{l}\text { (1) Repurchase authorizations with no } \\
\text { subsequent repurchase authorizations }\end{array}$ & $\begin{array}{l}0.2238^{\star \star} \\
{[2.058]} \\
13,673\end{array}$ & $\begin{array}{l}0.0928 \\
{[0.963]} \\
10,928\end{array}$ & $\begin{array}{c}0.0283 \\
{[0.300]} \\
9,568\end{array}$ & $\begin{array}{c}-0.0406 \\
-0.418] \\
8,860\end{array}$ \\
\hline $\begin{array}{l}\text { (2) Repurchase authorizations with } \\
\text { subsequent repurchase authorizations }\end{array}$ & $\begin{array}{l}0.2886^{\star \star} \\
{[2.579]} \\
4,620\end{array}$ & $\begin{array}{l}0.4238^{\star \star \star} \\
{[4.486]} \\
7,365\end{array}$ & $\begin{array}{l}0.4134^{* \star \star} \\
{[4.784]} \\
8,725\end{array}$ & $\begin{array}{l}0.4054^{\star \star \star} \\
{[4.775]} \\
9,433\end{array}$ \\
\hline Difference (1)-(2) & $\begin{array}{l}-0.0648 \\
{[-0.415]}\end{array}$ & $\begin{array}{l}-0.3311^{\star \star} \\
{[-2.445]}\end{array}$ & $\begin{array}{l}-0.3851^{* \star \star} \\
{[-2.991]}\end{array}$ & $\begin{array}{l}-0.4460^{\star \star \star} \\
{[-3.427]}\end{array}$ \\
\hline $\begin{array}{l}\text { (3) Repurchase authorizations with no } \\
\text { subsequent repurchase authorizations or } \\
\text { takeover announcements }\end{array}$ & $\begin{array}{l}0.1043 \\
{[0.961]} \\
12,584\end{array}$ & $\begin{array}{c}-0.0402 \\
{[-0.413]} \\
9,059\end{array}$ & $\begin{array}{c}-0.1069 \\
{[-1.118]} \\
7,268\end{array}$ & $\begin{array}{c}-0.1641^{\star} \\
{[-1.662]} \\
6,303\end{array}$ \\
\hline $\begin{array}{l}\text { (4) Repurchase programs with subsequent } \\
\text { repurchase authorizations or takeover } \\
\text { announcements }\end{array}$ & $\begin{array}{l}0.6281^{\star \star \star} \\
{[5.600]} \\
5,709\end{array}$ & $\begin{array}{l}0.5371^{\star \star \star} \\
{[5.827]} \\
9,234\end{array}$ & $\begin{array}{l}0.4694^{* \star \star} \\
{[5.433]} \\
11,025\end{array}$ & $\begin{array}{l}0.4157^{\star \star \star} \\
{[4.868]} \\
11,990\end{array}$ \\
\hline Difference (3)-(4) & $\begin{array}{l}-0.5238^{\star \star \star} \\
{[-3.356]}\end{array}$ & $\begin{array}{l}-0.5772^{\star \star \star} \\
{[-4.283]}\end{array}$ & $\begin{array}{l}-0.5763^{\star \star \star} \\
{[-4.442]}\end{array}$ & $\begin{array}{l}-0.5798^{\star \star \star} \\
{[-4.410]}\end{array}$ \\
\hline
\end{tabular}


FIGURE 3

Cumulative Alphas by Subsample

Figure 3 reflects long-run returns for various subsamples of the sample of 18,293 OMR program authorization announcements with monthly returns data from the Center for Research in Security Prices (CRSP). As indicated, subsamples are created on the basis of whether or not a subsequent repurchase or takeover announcement was made during the corresponding returns calculation period. Monthly abnormal returns $(\alpha)$ are estimated from Fama-French (1993) 3-factor calendar-time portfolio regressions: $R_{t}-R_{f, t}=\alpha_{1}+\beta_{1}\left(R_{m k t, t}-R_{f, t}\right)+\beta_{2} S M B_{t}+\beta_{3} H M L_{t}$, where $R_{t}$ is the return on an equal-weighted portfolio of stocks at time $t . R_{f, t}$ and $R_{m k t, t}$ are the risk-free rate and the return of the market at time $t . S M B_{t}$ and $H M L_{t}$ are the monthly returns on the Fama-French size and book-to-market factors in month $t$. The intercept term $(\alpha)$ of the regression represents the average monthly excess return in the event period. Cumulative alphas are calculated as the monthly abnormal returns times the number of months since the authorization.

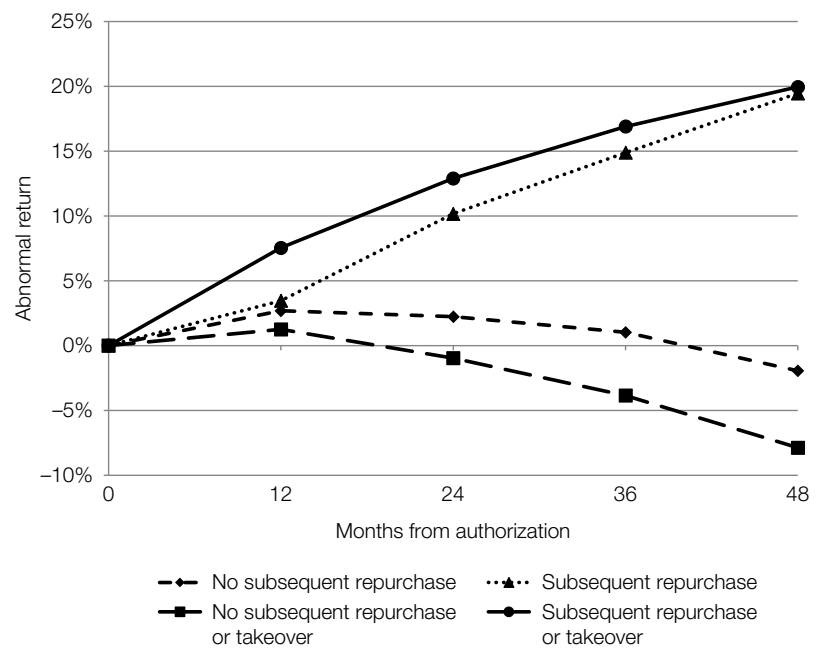

windows and that the differences between the subsamples are highly significant. Taken together, these additional findings demonstrate that the results for the subsample of OMRs with completion announcements generalize to the population of OMRs and that the positive and significant long-run abnormal returns following OMR authorizations documented in prior literature are substantially attributable to returns accompanying subsequent events.

In the subsample results presented in Tables 3 and 4, the composition of the subsamples changes across time windows based on the post-authorization timing of firms' subsequent OMR authorizations or takeover announcements. As the event windows lengthen, some firms migrate from the subsample with no subsequent announcements to the subsample with subsequent announcements. Allowing firms to migrate across subsamples preserves time consistency in the subsample populations; however, we have also conducted the subsample analysis, where we fix the subsample composition for each of the respective time windows based on firms' subsequent announcements over the entire 48-month post-authorization time window. The results when subsample composition is fixed are stronger in the 12-, 24-, and 36-month windows (48-month window results, by definition, are unchanged). Specifically, we no longer observe significantly positive alphas in any time period for the subsamples with no subsequent announcements, the differences across subsamples are larger in magnitude, and the differences are 
more often significant or significant at higher levels. These results are reported in Appendix Table B1.

ILV (1995) and PV (2009) find that positive post-OMR long-run drift is particularly prominent in the subsample of value firms. Thus, in Table 5, we report results based on the subsample of firms identified as value firms: firms in the lowest market-to-book quintile at the time of the authorization. As reported in Panel A,

\title{
TABLE 5
}

\section{Long-Run Abnormal Returns over Standard Windows: Additional Analysis}

\begin{abstract}
Table 5 examines the robustness of our full-sample long-run returns results. We make two modifications. First, we examine OMR program authorization announcements made by value firms, defined as firms in the lowest market-to-book quintile at the time of the authorization. Second, we reexamine OMR program authorization announcements for the full sample of firms, but we calculate alphas using a 4-factor model, which includes a momentum factor. Panel A presents abnormal returns over standard 12-, 24-, 36-, and 48-month windows beginning the month after the authorization announcement. Panels B and C present subsample analysis over standard windows; subsamples are created on the basis of whether a subsequent repurchase or takeover announcement was made during the corresponding returns calculation period. Monthly abnormal returns in Panel B $(\alpha)$ are estimated for value firms from Fama-French (1993) 3-factor calendar-time portfolio regressions. Monthly abnormal returns in Panel $\mathrm{C}$ are estimated from a 4-factor model, which includes momentum. The intercept term $(\alpha)$ of the regression represents the average monthly excess return in the event period. $t$-statistics are reported in square brackets with the number of repurchase programs reported below the $t$-statistics. *, **, and *** indicate significance at the $10 \%, 5 \%$, and $1 \%$ levels, respectively.
\end{abstract}

12 Months

12 Months

Panel A. $\alpha$ for Value Firms or Using a 4-Factor Model

Value firms

All authorizations (4-factor)

Panel B. $\alpha$ for Subsamples of Value Firms

(1) Repurchase authorizations with no subsequent repurchase authorizations

(2) Repurchase authorizations with subsequent repurchase authorizations

Difference (1) - (2)

(3) Repurchase authorizations with no subsequent repurchase authorizations or takeover announcements

(4) Repurchase programs with subsequent repurchase authorizations or takeover announcements

Difference (3) - (4)

Panel C. 4-Factor $\alpha$ for Subsamples of All Authorizations

(1) Repurchase authorizations with no subsequent repurchase authorizations

(2) Repurchase authorizations with Subsequent repurchase authorizations

Difference (1) - (2)

(3) Repurchase authorizations with no subsequent repurchase authorizations or takeover announcements

(4) Repurchase programs with subsequent repurchase authorizations or takeover announcements

Difference (3) - (4)

$\begin{array}{lccc}0.4717^{\star \star \star} & 0.3911^{\star \star \star} & 0.3152^{\star \star \star} & 0.2996^{\star \star} \\ {[3.366]} & {[3.109]} & {[2.614]} & {[2.555]} \\ 0.3818^{\star \star \star} & 0.307^{\star \star \star} & 0.2906^{\star \star \star} & 0.2751^{\star \star \star} \\ {[3.886]} & {[3.732]} & {[3.751]} & {[3.641]}\end{array}$

[3.626

2,191

0.0566

[0.241]

481

0.4979 *

[1.855]

$0.4118^{\text {** }}$

[2.786]

2,019

$0.9902^{\star \star \star}$

[3.716]

653

$-0.5784^{\text {** }}$

[-1.967]

\begin{tabular}{cccc}
$0.4201^{\star \star \star}$ & $0.2695^{\star \star \star}$ & $0.1981^{\star \star}$ & 0.1337 \\
{$[4.342]$} & {$[3.166]$} & {$[2.361]$} & {$[1.543]$} \\
13,673 & 10,928 & 9,568 & 8,860 \\
$0.359^{\star \star \star}$ & $0.4872^{\star \star \star}$ & $0.4872^{\star \star \star}$ & $0.4908^{\star \star \star}$ \\
{$[3.220]$} & {$[5.174]$} & {$[5.733]$} & {$[5.956]$} \\
4,620 & 7,365 & 8,725 & 9,433 \\
0.0611 & $-0.2177^{\star}$ & $-0.2891^{\star \star}$ & $-0.3571^{\star \star \star}$ \\
{$[0.416]$} & {$[-1.720]$} & {$[-2.418]$} & {$[-2.975]$} \\
$0.2983^{\star \star \star}$ & 0.1392 & 0.0614 & 0.0077 \\
{$[3.084]$} & {$[1.620]$} & {$[0.717]$} & {$[0.086]$} \\
12,584 & 9,059 & 7,268 & 6,303 \\
$0.7228^{\star \star \star}$ & $0.6131^{\star \star \star}$ & $0.5562^{\star \star \star}$ & $0.5135^{\star \star \star}$ \\
{$[6.568]$} & {$[6.744]$} & {$[6.633]$} & {$[6.286]$} \\
5,709 & 9,234 & 11,025 & 11,990 \\
$-0.4245^{\star \star \star}$ & $-0.4738^{\star \star \star}$ & $-0.4947^{\star \star \star}$ & $-0.5058^{\star \star \star}$ \\
{$[-2.908]$} & {$[-3.789]$} & {$[-4.117]$} & {$[-4.176]$} \\
\hline
\end{tabular}

$\begin{array}{ccc}0.3135^{\star \star} & 0.2178 & 0.1763 \\ {[2.173]} & {[1.518]} & {[1.270]} \\ 1,858 & 1,676 & 1,579 \\ 0.6171^{\star \star \star} & 0.5269^{\star \star \star} & 0.4773^{\star \star \star} \\ {[4.271]} & {[4.113]} & {[3.949]} \\ 814 & 996 & 1,093 \\ -0.3036 & -0.3091 & -0.301 \\ {[-1.486]} & {[-1.604]} & {[-1.628]} \\ 0.1798 & 0.1535 & 0.0787 \\ {[1.252]} & {[1.049]} & {[0.552]} \\ 1,566 & 1,314 & 1,175 \\ 0.7632^{\star \star \star} & 0.5554^{\star \star \star} & 0.4808^{\star \star \star} \\ {[5.072]} & {[4.338]} & {[3.844]} \\ 1,106 & 1,358 & 1,497 \\ -0.5834^{\star \star \star} & -0.4019^{\star \star} & -0.4021^{\star \star} \\ {[-2.806]} & {[-2.066]} & {[-2.116]}\end{array}$


we also observe larger long-run positive abnormal returns in this subsample. However, as indicated in Panel B, we also find that these returns are substantially attributable to subsequent repurchase and takeover announcements. Perhaps most striking is the difference in abnormal returns between the subsamples of firms with and without subsequent announcements. The differences in monthly abnormal returns are between $0.40 \%$ and $0.58 \%$, depending on the event window, and are statistically significant in all event windows.

Panel A of Table 5 also reports abnormal returns over standard windows for our full sample of authorizations when the momentum factor of Carhart (1997) is included in the market model. Including the momentum factor leads to larger estimated abnormal returns relative to the 3 -factor model (as reported in Table 4). However, as reported in Panel C, we continue to find that the abnormal performance is generally attributable to the subsamples of firms that experience subsequent takeover attempts and repurchase authorizations. Thus, our basic finding is generally robust to the inclusion of the momentum factor.

One question that arises is whether the positive long-run abnormal returns follow a driftlike pattern for the subsample of firms with subsequent OMR and takeover announcements or whether the returns are concentrated only in the months of the announcements. Thus, we calculate returns using the entire sample of authorizations with completion announcements and the entire sample of OMR programs, respectively, but remove particular firm-months that contain OMR authorizations or takeover announcements. Table 6 and Figure 1 present these results. In all cases, we see a reduction in average monthly excess returns when we exclude months with subsequent repurchase authorizations and a further reduction when we also exclude months with takeover announcements. When we exclude authorizations and takeovers, monthly excess returns are not different from 0 over any time window. Hence, as depicted in Figure 2, post-OMR abnormal returns behave more like step functions, with discrete positive abnormal returns at the announcements of subsequent events and insignificant returns between such announcements, as opposed to gradual persistent drifts. ${ }^{10}$

While there are well-documented advantages to using the Fama (1998) calendar-time portfolio approach, calculating firm-level buy-and-hold returns allows us to assess robustness to an alternative abnormal return methodology and facilitates additional firm-level tests. Thus, we follow Chan et al. (2004) and Chen and Wang (2012) and calculate buy-and-hold abnormal returns as the buy-andhold return on the sample firm minus the average buy-and-hold return of 5 size and book-to-market matched control firms. To select our control firms, we identify firms in the same size decile, based on the Center for Research in Security Prices (CRSP) market capitalization at the end of the month prior to the repurchase authorization. Next, within the size decile, we select firms that trade on the

\footnotetext{
${ }^{10}$ Since takeover announcements are often preceded by a run-up in the target firms' share prices (see, e.g., Betton, Eckbo, and Thorburn (2008)), we estimate long-run postcompletion returns excluding the months of the takeover announcements and the months prior to the takeover announcements. The results are stronger than those reported in Table 6; all coefficients fall in magnitude and significance.
} 
TABLE 6

Long-Run Abnormal Returns Including and Excluding Subsequent Events

Panels A and B of Table 6 present long-run abnormal returns for, respectively, the sample of 2,861 repurchase authorizations associated with completion announcements and the full sample of 18,293 repurchase authorizations. Where indicated, abnormal returns are calculated excluding firm-months during which a subsequent repurchase authorization is announced and months during which a takeover attempt is announced. Monthly abnormal returns $(\alpha)$ are estimated from Fama-French (1993) 3-factor calendar-time portfolio regressions: $R_{t}-R_{f, t}=\alpha_{1}+\beta_{1}\left(R_{m k t, t}-R_{f, t}\right)+\beta_{2} S M B_{t}+\beta_{3} H M L_{t}$, where $R_{t}$ is the return on an equally weighted portfolio of stocks at time $t$. $R_{f, t}$ and $R_{m k t, t}$ are the risk-free rate and the return of the market at time $t . S M B_{t}$ and $H M L_{t}$ are the monthly returns on the Fama-French size and book-to-market factors in month $t$. The intercept term $(\alpha)$ of the regression represents the average monthly excess return in the event period. $t$-statistics are reported in square brackets. ${ }^{*},{ }^{* *}$, and ${ }^{* * *}$ indicate significance at the $10 \%, 5 \%$, and $1 \%$ levels, respectively.

\begin{tabular}{|c|c|c|c|c|}
\hline Excluded Months & 12 Months & 24 Months & 36 Months & 48 Months \\
\hline \multicolumn{5}{|c|}{ Panel A. $\alpha$ for Authorizations with Completion Announcements } \\
\hline (1) None & $\begin{array}{l}0.3243^{\star \star} \\
{[2.384]}\end{array}$ & $\begin{array}{l}0.2868^{\star \star} \\
{[2.493]}\end{array}$ & $\begin{array}{l}0.2713^{\star *} \\
{[2.465]}\end{array}$ & $\begin{array}{l}0.2288^{\star \star} \\
{[2.148]}\end{array}$ \\
\hline (2) Subsequent repurchase authorizations & $\begin{array}{l}0.2621^{*} \\
{[1.930]}\end{array}$ & $\begin{array}{c}0.2087^{\star} \\
{[1.800]}\end{array}$ & $\begin{array}{c}0.2032^{*} \\
{[1.828]}\end{array}$ & $\begin{array}{c}0.1659 \\
{[1.549]}\end{array}$ \\
\hline (3) Subsequent authorizations and takeovers & $\begin{array}{c}0.1834 \\
{[1.348]}\end{array}$ & $\begin{array}{c}0.1319 \\
{[1.141]}\end{array}$ & $\begin{array}{c}0.1206 \\
{[1.089]}\end{array}$ & $\begin{array}{c}0.0795 \\
{[0.746]}\end{array}$ \\
\hline \multicolumn{5}{|l|}{ Panel B. $\alpha$ for All Authorizations } \\
\hline (1) None & $\begin{array}{c}0.2082^{*} \\
{[1.942]}\end{array}$ & $\begin{array}{c}0.1675^{\star} \\
{[1.879]}\end{array}$ & $\begin{array}{c}0.1632^{*} \\
{[1.955]}\end{array}$ & $\begin{array}{c}0.1465^{\star} \\
{[1.789]}\end{array}$ \\
\hline (2) Subsequent repurchase authorizations & $\begin{array}{c}0.1872^{\star} \\
{[1.747]}\end{array}$ & $\begin{array}{c}0.1456 \\
{[1.635]}\end{array}$ & $\begin{array}{c}0.1433^{*} \\
{[1.718]}\end{array}$ & $\begin{array}{c}0.1277 \\
{[1.564]}\end{array}$ \\
\hline (3) Subsequent authorizations and takeovers & $\begin{array}{c}0.0758 \\
{[0.711]}\end{array}$ & $\begin{array}{r}0.0292 \\
{[0.328]}\end{array}$ & $\begin{array}{c}0.0233 \\
{[0.281]}\end{array}$ & $\begin{array}{c}0.0086 \\
{[0.106]}\end{array}$ \\
\hline
\end{tabular}

same exchange. Finally, we choose the 5 firms closest in book-to-market ratio. ${ }^{11}$ We calculate buy-and-hold abnormal returns over 12-, 24-, 36-, and 48-month windows.

As reported in Panel A of Table 7, buy-and-hold returns are positive and significant in all cases except one, the 12-month returns to the subsample of OMRs with completions. Panels $\mathrm{B}$ and $\mathrm{C}$ of Table 7 report the results of regressions of buy-and-hold abnormal returns on the number of subsequent repurchase and takeover announcements in the various time windows for, respectively, the subsample of OMR authorizations with completion announcements and the full sample of authorizations. Coefficients on the number of subsequent repurchase announcements are generally positive and significant, though we do observe a negative and significant coefficient for the full sample for 12 -month returns. Nonetheless, especially for abnormal returns cumulated over longer time periods, we find that the number of repurchase authorizations has a significant positive impact on buy-and-hold returns. For example, for our full sample of OMR programs using a 48-month window, we find that each additional OMR authorization announcement is associated with $5.9 \%$ greater buy-and-hold abnormal return. The coefficients on

\footnotetext{
${ }^{11}$ Book-to-market is the ratio of the book value of the firm from Compustat at the end of the prior fiscal year, divided by market capitalization from CRSP at the end of the prior month. If a sample firm delists during the time window, then we use the buy-and-hold abnormal returns from the first month until the delisting as the abnormal returns for the entire time window. (Essentially, we are assuming that abnormal returns are 0 for the remainder of the time window.) If a control firm drops from our sample, we assume that proceeds at the time of the delisting are invested in the equal-weighted CRSP index.
} 
TABLE 7

Buy-and-Hold Abnormal Returns Analysis

Panel A of Table 7 presents average abnormal buy-and-hold returns for repurchase authorizations associated with completion announcements and the full sample of repurchase authorizations. Abnormal buy-and-hold returns are calculated as the buy-and-hold return on the OMR firm minus the average buy-and-hold return of 5 size and book-to-market matched control firms. Panels $\mathrm{B}$ and $\mathrm{C}$ report the results of regressions explaining abnormal buy-and-hold returns for the respective samples. Number of repurchase (takeover) announcements is the number of subsequent OMR (takeover) announcements that occur during the return calculation period. $t$-statistics are reported in square brackets and robust standard errors are clustered by firm. * ${ }^{* *}$, and ${ }^{* *}$ indicate significance at the $10 \%, 5 \%$, and $1 \%$ levels, respectively.

\begin{tabular}{|c|c|c|c|c|}
\hline \multirow{2}{*}{\multicolumn{5}{|c|}{ Panel A. Average Abnormal Buy-and-Hold Returns }} \\
\hline & & & & \\
\hline Authorizations with completion announcements & $\begin{array}{l}-0.0018 \\
{[-0.203]}\end{array}$ & $\begin{array}{l}0.0337^{\star *} \\
{[2.448]}\end{array}$ & $\begin{array}{l}0.0653^{\star \star \star} \\
{[3.542]}\end{array}$ & $\begin{array}{l}0.0902^{\star \star \star} \\
{[4.149]}\end{array}$ \\
\hline All authorizations & $\begin{array}{l}0.0084^{\star \star} \\
{[2.143]}\end{array}$ & $\begin{array}{l}0.0240^{\star * \star} \\
{[3.815]}\end{array}$ & $\begin{array}{l}0.0434^{\star \star \star} \\
{[5.528]}\end{array}$ & $\begin{array}{l}0.0549^{* \star *} \\
{[5.848]}\end{array}$ \\
\hline
\end{tabular}

Panel B. Regressions Explaining Buy-and-Hold Returns for Sample of Authorizations with Completion Announcements

\begin{tabular}{|c|c|c|c|c|}
\hline Number of repurchase announcements & $\begin{array}{l}-0.0092 \\
{[-0.728]}\end{array}$ & $\begin{array}{c}0.0158 \\
{[1.183]}\end{array}$ & $\begin{array}{l}0.0275^{\star} \\
{[1.915]}\end{array}$ & $\begin{array}{l}0.0488^{* * *} \\
{[3.084]}\end{array}$ \\
\hline Number of takeover announcements & $\begin{array}{l}0.2000^{\star \star \star} \\
{[3.994]}\end{array}$ & $\begin{array}{l}0.1707^{\star \star *} \\
{[3.854]}\end{array}$ & $\begin{array}{l}0.1293^{\star \star} \\
{[2.479]}\end{array}$ & $\begin{array}{l}0.1578^{\star * *} \\
{[2.895]}\end{array}$ \\
\hline Constant & $\begin{array}{l}-0.0034 \\
{[-0.280]}\end{array}$ & $\begin{array}{c}-0.0043 \\
{[-0.187]}\end{array}$ & $\begin{array}{r}0.0001 \\
{[0.002]}\end{array}$ & $\begin{array}{l}-0.0349 \\
{[-0.873]}\end{array}$ \\
\hline $\begin{array}{l}\text { No. of obs. } \\
\text { Adj. } R^{2}\end{array}$ & $\begin{array}{l}2,607 \\
0.007\end{array}$ & $\begin{array}{l}2,607 \\
0.006\end{array}$ & $\begin{array}{l}2,607 \\
0.004\end{array}$ & $\begin{array}{l}2,607 \\
0.009\end{array}$ \\
\hline \multicolumn{5}{|c|}{ Panel C. Regressions Explaining Buy-and-Hold Returns for All Authorizations } \\
\hline Number of repurchase announcements & $\begin{array}{l}-0.0138^{\star \star} \\
{[-1.967]}\end{array}$ & $\begin{array}{l}0.0162^{\star *} \\
{[1.980]}\end{array}$ & $\begin{array}{l}0.0359^{\star \star \star} \\
{[3.776]}\end{array}$ & $\begin{array}{l}0.0592^{* * *} \\
{[5.122]}\end{array}$ \\
\hline Number of takeover announcements & $\begin{array}{c}0.1732^{\star \star \star} \\
{[11.621]}\end{array}$ & $\begin{array}{c}0.1661^{* \star *} \\
{[10.528]}\end{array}$ & $\begin{array}{l}0.1613^{\star \star \star} \\
{[9.125]}\end{array}$ & $\begin{array}{l}0.1675^{\star * *} \\
{[8.054]}\end{array}$ \\
\hline Constant & $\begin{array}{c}-0.0003 \\
{[-0.063]}\end{array}$ & $\begin{array}{l}-0.0121 \\
{[-1.384]}\end{array}$ & $\begin{array}{l}-0.0235^{\star} \\
{[-1.939]}\end{array}$ & $\begin{array}{l}-0.0527^{\star \star *} \\
{[-3.367]}\end{array}$ \\
\hline $\begin{array}{l}\text { No. of obs. } \\
\text { Adj. } R^{2}\end{array}$ & $\begin{array}{r}16,645 \\
0.011\end{array}$ & $\begin{array}{r}16,645 \\
0.007\end{array}$ & $\begin{array}{r}16,645 \\
0.007\end{array}$ & $\begin{array}{c}16,645 \\
0.009\end{array}$ \\
\hline
\end{tabular}

the takeover announcements variable are large, positive, and highly significant in all cases. Interestingly, the constants in the regressions are in no cases positive and significant and in two cases negative and significant. The lack of positive and significant constants suggests insignificant long-run abnormal returns after controlling for the effects of subsequent announcements. ${ }^{12,13}$

\section{E. Underreaction vs. Misspecification of the Model for Expected Returns}

While our analysis to this point is not structured as an effort to cause the postOMR returns anomaly to disappear, the results of the analysis indicate where such effort should be directed. Specifically, insofar as the underreaction observed over the standard event windows reflects potential misspecification of the model for expected returns, the potential misspecification appears related to changes in the

\footnotetext{
${ }^{12}$ We have also conducted this analysis using the subsample approach and again find that excess returns are driven by firms in the subsamples with subsequent repurchase authorization or takeover announcements. These results are reported in Appendix Table B2.

${ }^{13}$ We have conducted all of the analyses reported in Tables 6 and 7 of our paper on the subsample of value firms. We continue to observe larger long-run positive abnormal returns in this subsample, but we find that these returns are substantially attributable to the effects of subsequent repurchase and takeover announcements. These results are reported in Appendix Tables B3 and B4.
} 
expected returns from subsequent OMR authorizations and takeover attempts. While constructing a "repurchase" factor is beyond the scope of this paper, we investigate the effects on observed post-OMR abnormal returns of adding a takeover-risk factor to the expected returns model. We closely follow CNJ (2009) in estimating the ex ante probability that a firm will be the target of a takeover attempt in the next year, sorting firms into yearly quintiles based on ex ante takeover probability, and calculating monthly returns to long-short portfolios that buy firms in the highest ex ante takeover probability quintile and short firms in the lowest quintile. ${ }^{14}$ These returns, thus, comprise a factor that reflects firms' ex ante differential exposure to takeover likelihood and the underlying state variables affecting asset prices.

Panel A of Table 8 presents alphas for the subsample of OMR programs with completion announcements, and Panel B presents the same for our full sample of OMR programs. Panel C presents alphas for all authorization announcements made by value firms, and Panel $\mathrm{D}$ reports results when abnormal returns for all authorizations are estimated, including the momentum factor of Carhart (1997). In all cases, including the takeover factor greatly reduces the magnitudes of the alphas and renders them almost uniformly insignificant. Lin et al. (2014) also find that the addition of a takeover factor to the 3-factor model yields an estimated alpha that is indistinguishable from 0 for their sample of repurchasing firms.

When we include the CNJ (2009) takeover factor and bifurcate our sample, our results are similar to those from our prior subsample analysis. Namely, we fail to observe positive and significant abnormal returns in the subsample of repurchase authorizations associated with a subsequent repurchase or takeover announcement, and we generally observe positive and significant abnormal returns in the subsample with subsequent announcements. In all cases, the difference in alphas across the two subsamples is significant. These results suggest that including the takeover factor in our asset pricing model does not cause these returns differentials to disappear.

Insofar as the takeover factor developed in CNJ (2009) is a proxy for an additional risk factor, post-OMR abnormal returns being reduced to 0 with the inclusion of the takeover factor is consistent with an interpretation that the abnormal returns are attributable to takeover risk and not to underreaction on the part of market participants. ${ }^{15}$ However, taken together, the overall pattern of results from all of our analyses is inconsistent with a straightforward takeover-risk based explanation for the repurchase anomaly. In particular, we observe reliably positive abnormal returns only in the subsample of firms with subsequent takeovers or OMR announcements, yet this subsample of firms is significantly less exposed to the takeover risk factor, as reported in Table 9. Thus, the subsample of firms with greater exposure to takeover risk does not exhibit significant abnormal returns, whereas the subsample of firms with less exposure does. The Table 8

\footnotetext{
${ }^{14}$ Results of the logit regression used to estimate takeover probabilities are reported in Appendix Table B5.

${ }^{15}$ Cremers et al. (2009) note, however, that separating the effects of covariance and characteristics is difficult because of the high correlation between the takeover betas and the average portfolio takeover likelihood in their sample.
} 


\section{TABLE 8}

\section{Long-Run Abnormal Returns Including and Excluding Takeover Factor}

Panels A and B of Table 8 present long-run abnormal returns for, respectively, the sample of 2,861 repurchase authorizations associated with completion announcements and the full sample of 18,293 repurchase authorizations. Monthly abnormal returns $(\alpha)$ are estimated from Fama-French (1993) 3-factor calendar-time portfolio regressions: $R_{t}-R_{f, t}=$ $\alpha_{1}+\beta_{1}\left(R_{m k t, t}-R_{f, t}\right)+\beta_{2} S M B_{t}+\beta_{3} H M L_{t}$, where $R_{t}$ is the return on an equal-weighted portfolio of stocks at time $t$. $R_{f, t}$ and $R_{m k t, t}$ are the risk-free rate and the return of the market at time $t . S M B_{t}$ and $H M L_{t}$ are the monthly returns on the Fama-French size and book-to-market factors in month $t$. When noted, the Cremers, Nair, and John (CNJ) (2009) takeover factor is included as a fourth factor. The intercept term $(\alpha)$ of the regression represents the average monthly excess return in the event period. Panel C presents long-run returns for OMR program authorization announcements made by value firms, defined as firms in the lowest market-to-book quintile at the time of the authorization. Panel $D$ reports results when abnormal returns are estimated from a 4 -factor model that includes momentum. $t$-statistics are reported in square brackets. ${ }^{*},{ }^{\star \star}$, and ${ }^{* * *}$ indicate significance at the $10 \%, 5 \%$, and $1 \%$ levels, respectively.

$\frac{\text { CNJ Takeover Factor }}{\underline{\text { Panel A. } \alpha \text { for Authorizations with Completion Announcements }}}$

(1) Excluded
(2) Included
(3) Included: Repurchase authorizations with no subsequent
repurchase authorizations or takeover announcements
(4) Included: Repurchase programs with subsequent
repurchase authorizations or takeover announcements
Difference (3) - (4)

12 Months 24 Months

36 Months

48 Months

\section{Panel B. $\alpha$ for All Authorizations}

(1) Excluded

(2) Included

(3) Included: Repurchase authorizations with no subsequent repurchase authorizations or takeover announcements

$0.3243^{\star \star}$
$[2.384]$
0.1054
$[0.788]$

\begin{tabular}{|c|c|c|}
\hline $\begin{array}{l}0.2868^{* *} \\
{[2.493]}\end{array}$ & $\begin{array}{l}0.2713^{\star *} \\
{[2.465]}\end{array}$ & $\begin{array}{l}0.2288^{\star \star} \\
{[2.148]}\end{array}$ \\
\hline $\begin{array}{c}0.1205 \\
{[1.079]}\end{array}$ & $\begin{array}{r}0.0715 \\
{[0.684]}\end{array}$ & $\begin{array}{c}0.0212 \\
{[0.213]}\end{array}$ \\
\hline & $\begin{array}{l}-0.2256 \\
{[-1.644]}\end{array}$ & $\begin{array}{l}-0.3819^{\star \star \star} \\
{[-2.732]}\end{array}$ \\
\hline $\begin{array}{l}0.3346^{\star \star \star} \\
{[2.583]}\end{array}$ & $\begin{array}{l}0.2360^{\star *} \\
{[2.043]}\end{array}$ & $\begin{array}{r}0.1631 \\
{[1.535]}\end{array}$ \\
\hline $\begin{array}{l}6^{\star \star \star} \\
]^{2}\end{array}$ & $\begin{array}{l}-0.4616^{\star \star *} \\
{[-2.565]}\end{array}$ & $\begin{array}{l}-0.5450^{\star \star \star} \\
{[-3.127]}\end{array}$ \\
\hline
\end{tabular}

(4) Included: Repurchase programs with subsequent repurchase authorizations or takeover announcements

Difference (3) - (4)

\section{$\underline{\text { Panel C. } \alpha \text { for Value Firms }}$}

(1) Excluded

(2) Included

(3) Included: Repurchase authorizations with no subsequent repurchase authorizations or takeover announcements

(4) Included: Repurchase programs with subsequent repurchase authorizations or takeover announcements

Difference (3) - (4)

\section{Panel D. 4-Factor $\alpha$ for All Authorizations}

(1) Excluded

(2) Included

(3) Included: Repurchase authorizations with no subsequent repurchase Authorizations or takeover announcements

(4) Included: Repurchase programs with subsequent repurchase authorizations or takeover announcements

$-0.0454$

$[-0.318]$

$0.3327^{*}$

[1.854]

$-0.3781^{*}$

[-1.656]

$[-2.945]$

$[-2.565]$

[-3.127]

\begin{tabular}{|c|c|c|c|}
\hline $\begin{array}{c}0.2082^{\star} \\
{[1.942]}\end{array}$ & $\begin{array}{c}0.1675^{*} \\
{[1.879]}\end{array}$ & $\begin{array}{c}0.1632^{*} \\
{[1.955]}\end{array}$ & $\begin{array}{c}0.1465^{\star} \\
{[1.789]}\end{array}$ \\
\hline $\begin{array}{l}-0.0199 \\
{[-0.230]}\end{array}$ & $\begin{array}{l}-0.0074 \\
{[-0.100]}\end{array}$ & $\begin{array}{l}-0.0543 \\
{[-0.789]}\end{array}$ & $\begin{array}{l}-0.0757 \\
{[-1.131]}\end{array}$ \\
\hline $\begin{array}{l}-0.1347 \\
{[-1.512]}\end{array}$ & $\begin{array}{l}-0.2626^{\star \star \star} \\
{[-3.250]}\end{array}$ & $\begin{array}{l}-0.392^{\star \star \star} \\
{[-4.874]}\end{array}$ & $\begin{array}{l}-0.4615^{\star \star \star} \\
{[-5.504]}\end{array}$ \\
\hline $\begin{array}{l}0.3751^{\star \star \star} \\
{[3.459]}\end{array}$ & $\begin{array}{l}0.3331^{\text {*** }} \\
{[3.758]}\end{array}$ & $\begin{array}{l}0.2376^{* * *} \\
{[2.995]}\end{array}$ & $\begin{array}{l}0.1876^{\star \star \star} \\
{[2.430]}\end{array}$ \\
\hline $\begin{array}{l}-0.5098^{\star \star \star} \\
{[-3.650]}\end{array}$ & $\begin{array}{l}-0.5957^{\star \star \star} \\
{[-4.975]}\end{array}$ & $\begin{array}{l}-0.6296^{* * *} \\
{[-5.569]}\end{array}$ & $\begin{array}{l}-0.6491^{\star \star \star} \\
{[-5.687]}\end{array}$ \\
\hline
\end{tabular}

$\begin{array}{cccc}0.4717^{\star \star \star} & 0.3911^{\star \star \star} & 0.3152^{\star \star \star} & 0.2996^{\star \star} \\ {[3.366]} & {[3.109]} & {[2.614]} & {[2.555]} \\ 0.1399 & 0.0223 & -0.0432 & -0.0706 \\ {[1.078]} & {[0.205]} & {[-0.443]} & {[-0.768]} \\ 0.0641 & -0.2722^{\star \star \star} & -0.3593^{\star \star \star} & -0.3816^{\star \star \star} \\ {[0.461]} & {[-2.263]} & {[-3.065]} & {[-3.431]} \\ 0.6736^{\star \star \star} & 0.5233^{\star \star \star} & 0.2494^{\star \star \star} & 0.1479 \\ {[2.496]} & {[3.439]} & {[2.117]} & {[1.335]} \\ -0.6095^{\star \star \star} & -0.7955^{\star \star \star} & -0.6087^{\star \star \star} & -0.5296^{\star \star \star} \\ {[-2.081]} & {[-4.109]} & {[-3.663]} & {[-3.372]}\end{array}$

\begin{tabular}{lccc}
$0.3818^{\star \star \star}$ & $0.3070^{\star \star \star}$ & $0.2906^{\star \star \star}$ & $0.2751^{\star \star \star}$ \\
{$[3.886]$} & {$[3.732]$} & {$[3.751]$} & {$[3.641]$} \\
$0.1529^{\star}$ & 0.1137 & 0.0492 & 0.0279 \\
{$[1.805]$} & {$[1.553]$} & {$[0.713]$} & {$[0.416]$} \\
0.0700 & -0.0916 & $-0.2415^{\star \star \star}$ & $-0.3108^{\star \star \star}$ \\
{$[0.828]$} & {$[-1.185]$} & {$[-3.076]$} & {$[-3.777]$} \\
$0.4500^{\star \star \star}$ & $0.3820^{\star \star \star}$ & $0.2969^{\star \star \star}$ & $0.2633^{\star \star \star}$ \\
{$[3.996]$} & {$[4.135]$} & {$[3.606]$} & {$[3.312]$} \\
$-0.3800^{\star \star \star}$ & $-0.4736^{\star \star \star}$ & $-0.5383^{\star \star *}$ & $-0.5741^{\star \star \star}$ \\
$-2.719]$ & {$[-3.948]$} & {$[-4.735]$} & {$[-5.014]$} \\
\hline
\end{tabular}

Difference (3) - (4) 
TABLE 9

Takeover Betas for Subsamples of All Authorizations Subsample

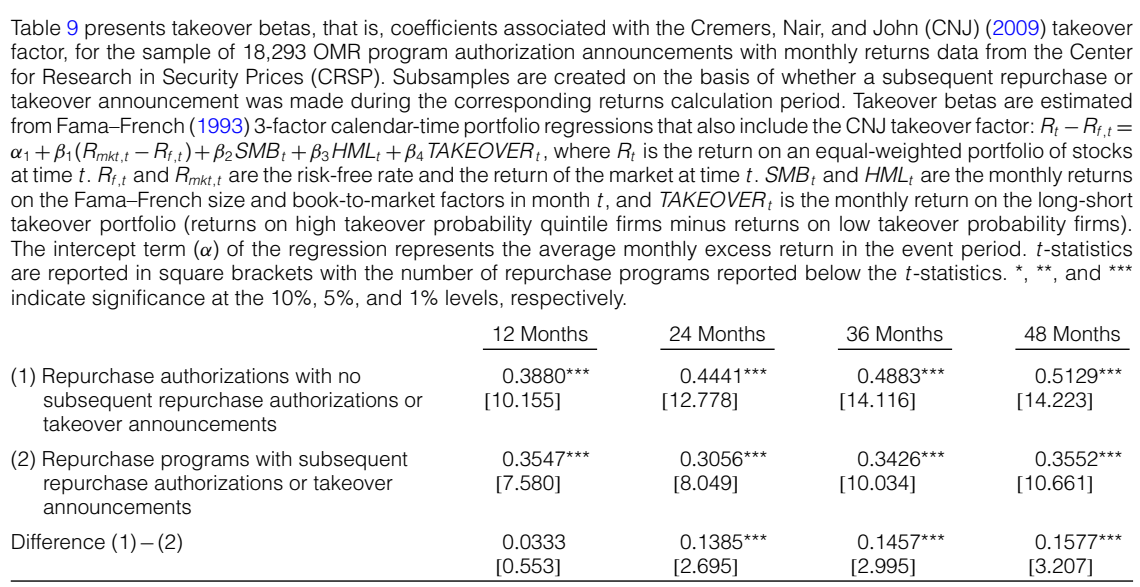

finding that the returns differential between the firms with and without subsequent takeovers or OMR announcements persists when we include the takeover factor in our model reinforces the Table 9 evidence that exposure to the takeover factor is not concentrated in the firms with subsequent takeovers.

We also find in Table 6 that abnormal returns are specific to the firm-months in which takeovers are announced. However, if the observed abnormal returns are due to the failure to account for takeover risk, then we would expect the abnormal returns to accrue somewhat steadily over the periods following OMR announcements. This expectation should hold unless takeover risk premiums are also largely confined to the specific firm-months in which takeovers are announced. The correlation between the number of firm-month returns deleted in Table 6 due to actual takeover or OMR announcements and the monthly return on the high minus low takeover probability portfolio is only 0.006 , which suggests that abnormal returns attributable to takeover risk should not be specific to only the firm-months of actual takeover announcements. In sum, our results cast doubt on the risk factor explanation for the positive abnormal returns following repurchase authorizations. Insofar as the risk factor explanation applies, we show that these stocks' risk premia are concentrated around a few relatively infrequent events (i.e., subsequent takeover and OMR announcements).

\section{Conclusions}

This paper improves our understanding of the timing and source of the seemingly anomalous positive long-run post-OMR returns documented in prior literature. We find that abnormal returns between authorizations and completions are indistinguishable from 0 and that positive returns come only after completions. We find robust evidence that the positive long-run returns following authorizations are largely attributable to the positive announcement returns at subsequent authorizations and takeover attempts. Thus, post-OMR abnormal returns are 
generally step functions, not gradual persistent drifts. Taken together, these results have important implications for the conclusions reached in prior papers investigating the repurchase anomaly. Further, our findings indicate that search for a rational explanation for the repurchase anomaly should refocus on the potential sources first proposed in ILV (1995).

\section{Appendix A. Search Details and Completion Announcement Examples}

\section{Search Terms and Sources}

The search terms for completions were "(share or shares or equity or stock) and (repur* or buyback* or buy-back* or buy* back) NEAR5 (complet* or conclud*)." The sources for the search were "Publication: Business Wire or Publication: PR Newswire (U.S.) or Publication: Major News and Business Publications: U.S."

\section{Sample Completion Announcement without a Concurrent New Authorization}

Excerpt from June 17, 2007 Business Wire article "Gilead Sciences Completes \$1 Billion Stock Repurchase Program":

Gilead Sciences, Inc. (NASDAQ:GILD) today announced that it has completed the $\$ 1.0$ billion stock repurchase program that was authorized by its Board of Directors in March 2006. Under the buyback program, Gilead acquired approximately 8.4 million shares of its common stock at an average price of $\$ 65.13$ per share, representing a total of $\$ 544.9$ million, in connection with a $\$ 1.3$ billion convertible notes offering completed in April 2006 and subsequently used the remaining $\$ 455.1$ million to acquire approximately 5.6 million shares of common stock at an average price of $\$ 81.02$ per share. Upon completion of the stock repurchase program on June 18, 2007, the company had approximately 468,090,700 shares outstanding, excluding stock options and unvested restricted shares.

\section{Sample Completion Announcement with a Concurrent New Authorization}

Excerpt from Apr. 29, 2004 PR Newswire article "E*TRADE FINANCIAL Corporation Announces the Completion of its $\$ 100$ Million Repurchase Program and the Authorization of a New \$200 Million Repurchase Program”:

E*TRADE FINANCIAL Corporation announced today that it has completed its $\$ 100$ million repurchase program authorized by the Board of Directors on December 17, 2003. Through the program, the Company repurchased approximately 7.85 million shares at a weighted average price of $\$ 12.73$. In addition, the Company announced that its Board of Directors has authorized a new $\$ 200$ million repurchase program. The new plan is not subject to a specific end date and provides the flexibility to buy back common stock, redeem for cash its outstanding $6.75 \%$ Convertible Subordinated Notes, retire debt in the open market or a combination of all three. 


\section{Appendix B. Robustness Tests}

In Appendix B, we verify the robustness of several of our main results. Appendix Table B1 presents Tables 3 and 4 when we use a fixed subsample based on firms' subsequent announcements over the full 48-month window. In Appendix Table B2, we provide results from subsample analysis using buy-and-hold returns. In Appendix Tables B3 and B4, we replicate results from Tables 6 and 7, respectively, using the subsample of value firms. Finally, in Appendix Table B5, we include our takeover probability model used to construct the takeover factor.

\section{TABLE B1}

\section{Long-Run Abnormal Returns for Constant Composition Subsamples}

Panels A and B of Appendix Table B1 present long-run abnormal returns for, respectively, repurchase authorizations associated with completion announcements and the full sample of repurchase authorizations. Constant composition subsamples are created on the basis of whether a subsequent repurchase or takeover announcement was made any time during the 48 months following a repurchase authorization. Monthly abnormal returns $(\alpha)$ are estimated from FamaFrench (1993) 3-factor calendar-time portfolio regressions: $R_{t}-R_{f, t}=\alpha_{1}+\beta_{1}\left(R_{m k t, t}-R_{f, t}\right)+\beta_{2} S M B_{t}+\beta_{3} H M L_{t}$, where $R_{t}$ is the return on an equal-weighted portfolio of stocks at time $t$. $R_{f, t}$ and $R_{m k t, t}$ are the risk-free rate and the return of the market at time $t . S M B_{t}$ and $H M L_{t}$ are the monthly returns on the Fama-French size and book-to-market factors in month $t$. The intercept term $(\alpha)$ of the regression represents the average monthly excess return in the event period. $t$-statistics are reported in square brackets with the number of repurchase programs reported below the $t$-statistics. ${ }^{\star},{ }^{\star *}$, and ${ }^{* \star *}$ indicate significance at the $10 \%, 5 \%$, and $1 \%$ levels, respectively.

\begin{tabular}{|c|c|c|c|c|}
\hline \multirow{2}{*}{\multicolumn{5}{|c|}{ Panel A. $\alpha$ for Constant Composition Subsamples of Authorizations with Completion Announcements }} \\
\hline & & & & \\
\hline $\begin{array}{l}\text { (1) Repurchase authorizations with no } \\
\text { subsequent repurchase authorizations }\end{array}$ & $\begin{array}{c}0.0563 \\
{[0.254]} \\
669\end{array}$ & $\begin{array}{c}0.0378 \\
{[0.242]} \\
669\end{array}$ & $\begin{array}{c}0.0924 \\
{[0.625]} \\
669\end{array}$ & $\begin{array}{c}-0.0163 \\
{[-0.121]} \\
669\end{array}$ \\
\hline $\begin{array}{l}\text { (2) Repurchase authorizations with } \\
\text { subsequent repurchase authorizations }\end{array}$ & $\begin{array}{l}0.3950^{\star * *} \\
{[2.658]} \\
2,269\end{array}$ & $\begin{array}{l}0.4821^{\star \star *} \\
{[3.806]} \\
2,269\end{array}$ & $\begin{array}{l}0.4508^{\star \star \star} \\
{[3.883]} \\
2,269\end{array}$ & $\begin{array}{l}0.4209^{\star \star \star} \\
{[3.752]} \\
2,269\end{array}$ \\
\hline Difference (1)-(2) & $\begin{array}{l}-0.3387 \\
{[-1.316]}\end{array}$ & $\begin{array}{l}-0.4443^{\star \star} \\
{[-2.233]}\end{array}$ & $\begin{array}{l}-0.3584^{\star} \\
{[-1.906]}\end{array}$ & $\begin{array}{l}-0.4372^{\star \star} \\
{[-2.478]}\end{array}$ \\
\hline $\begin{array}{l}\text { (3) Repurchase authorizations with no } \\
\text { subsequent repurchase authorizations or } \\
\text { takeover announcements }\end{array}$ & $\begin{array}{c}0.0364 \\
{[0.135]} \\
480\end{array}$ & $\begin{array}{c}-0.0970 \\
{[-0.560]} \\
480\end{array}$ & $\begin{array}{c}-0.1496 \\
{\left[\begin{array}{c}-0.980] \\
480\end{array}\right.}\end{array}$ & $\begin{array}{c}-0.0840 \\
{[-0.580]} \\
480\end{array}$ \\
\hline $\begin{array}{l}\text { (4) Repurchase programs with subsequent } \\
\text { repurchase authorizations or takeover } \\
\text { announcements }\end{array}$ & $\begin{array}{l}0.4136^{* * *} \\
{[2.900]} \\
2,458\end{array}$ & $\begin{array}{l}0.5121^{\star * *} \\
{[4.125]} \\
2,458\end{array}$ & $\begin{array}{l}0.4637^{\star * \star} \\
{[3.942]} \\
2,458\end{array}$ & $\begin{array}{l}0.4124^{\star \star \star} \\
{[3.664]} \\
2,458\end{array}$ \\
\hline Difference $(3)-(4)$ & $\begin{array}{l}-0.3772 \\
{[-1.361]}\end{array}$ & $\begin{array}{l}-0.6091^{\star \star \star} \\
{[-2.937]}\end{array}$ & $\begin{array}{l}-0.6133^{\star \star \star} \\
{[-3.230]}\end{array}$ & $\begin{array}{l}-0.4964^{\star \star *} \\
{[-2.716]}\end{array}$ \\
\hline
\end{tabular}

Panel B. $\alpha$ for Constant Composition Subsamples of All Authorizations

\begin{tabular}{|c|c|c|c|c|}
\hline $\begin{array}{l}\text { (1) Repurchase authorizations with no } \\
\text { subsequent repurchase authorizations }\end{array}$ & $\begin{array}{c}0.0173 \\
{[0.140]} \\
8,860\end{array}$ & $\begin{array}{c}-0.0282 \\
{[-0.266]} \\
8,860\end{array}$ & $\begin{array}{c}-0.0480 \\
{[-0.481]} \\
8,860\end{array}$ & $\begin{array}{c}-0.0406 \\
{[-0.418]} \\
8,860\end{array}$ \\
\hline $\begin{array}{l}\text { (2) Repurchase authorizations with } \\
\text { subsequent repurchase authorizations }\end{array}$ & $\begin{array}{l}0.4947^{* * *} \\
{[5.084]} \\
9,433\end{array}$ & $\begin{array}{l}0.4880^{* * *} \\
{[5.522]} \\
9,433\end{array}$ & $\begin{array}{l}0.4435^{\star * *} \\
{[5.212]} \\
9,433\end{array}$ & $\begin{array}{l}0.4054^{\star \star \star} \\
{[4.775]} \\
9,433\end{array}$ \\
\hline Difference (1) - (2) & $\begin{array}{l}-0.4774^{\star \star \star} \\
{[-3.036]}\end{array}$ & $\begin{array}{l}-0.5161^{\star \star *} \\
{[-3.722]}\end{array}$ & $\begin{array}{l}-0.4915^{\star \star \star} \\
{[-3.713]}\end{array}$ & $\begin{array}{l}-0.4460^{\star \star \star} \\
{[-3.427]}\end{array}$ \\
\hline $\begin{array}{l}\text { (3) Repurchase authorizations with no } \\
\text { subsequent repurchase authorizations or } \\
\text { takeover announcements }\end{array}$ & $\begin{array}{c}-0.1729 \\
{[-1.346]} \\
6,303\end{array}$ & $\begin{array}{c}-0.1791 \\
{[-1.645]} \\
6,303\end{array}$ & $\begin{array}{c}-0.1896^{\star} \\
{[-1.848]} \\
6,303\end{array}$ & $\begin{array}{c}-0.1641^{*} \\
{[-1.662]} \\
6,303\end{array}$ \\
\hline $\begin{array}{l}\text { (4) Repurchase programs with subsequent } \\
\text { repurchase authorizations or takeover } \\
\text { announcements }\end{array}$ & $\begin{array}{l}0.5375^{\star \star \star} \\
{[5.715]} \\
11,990\end{array}$ & $\begin{array}{l}0.5003^{\star \star \star} \\
{[5.709]} \\
11,990\end{array}$ & $\begin{array}{l}0.4602^{\star \star \star} \\
{[5.389]} \\
11,990\end{array}$ & $\begin{array}{l}0.4157^{\star \star \star} \\
{[4.868]} \\
11,990\end{array}$ \\
\hline Difference (3)-(4) & $\begin{array}{l}-0.7104^{* * *} \\
{[-4.461]}\end{array}$ & $\begin{array}{l}-0.6795^{\star \star \star} \\
{[-4.833]}\end{array}$ & $\begin{array}{l}-0.6498^{\star * *} \\
{[-4.826]}\end{array}$ & $\begin{array}{l}-0.5798^{\star \star \star} \\
{[-4.410]}\end{array}$ \\
\hline
\end{tabular}


TABLE B2

\section{Buy-and-Hold Abnormal Returns by Subsample}

Panels A and B of Appendix Table B2 present buy-and-hold abnormal returns for, respectively, repurchase authorizations associated with completion announcements and the full sample of repurchase authorizations. Abnormal buy-and-hold returns are calculated as the buy-and-hold return on the OMR firm minus the average buy-and-hold return of 5 size and book-to-market matched control firms. We present subsample analysis over standard windows; subsamples are created on the basis of whether a subsequent repurchase or takeover announcement was made during the corresponding returns calculation period. $t$-statistics are reported in square brackets with the number of repurchase programs reported below the $t$-statistics. ${ }^{*},{ }^{* *}$, and ${ }^{* * *}$ indicate significance at the $10 \%, 5 \%$, and $1 \%$ levels, respectively.

\section{Months \\ 24 Months $\quad 36$ Months \\ 48 Months}

Panel A. Authorizations with Completion Announcements

(1) Repurchase authorizations with no subsequent repurchase authorizations

\subsection{1}

[0.501]

1,365

(2) Repurchase authorizations with subsequent repurchase authorizations

Difference (1) - (2)

(3) Repurchase authorizations with no subsequent repurchase authorizations or takeover announcements

(4) Repurchase programs with subsequent Repurchase authorizations or takeover announcements

Difference (3) - (4)

\section{Panel B. All Authorizations}

(1) Repurchase authorizations with no subsequent repurchase authorizations

(2) Repurchase authorizations with Subsequent repurchase authorizations

Difference (1) - (2)

(3) Repurchase authorizations with no subsequent repurchase authorizations or takeover announcements

(4) Repurchase programs with subsequent repurchase authorizations or takeover announcements

Difference (3) - (4)

\section{$-0.0106$}

[-0.789]

1,242

0.0167

[0.923]

$-0.0035$

[-0.281]

1,308

$-0.0002$

[-0.014]

1,299

$-0.0033$

[-0.182]

0.0226
$[0.868]$
871
$0.0393^{\star *}$
$[2.136]$
1,736
-0.0167
$[-0.525]$
-0.0153
$[-0.535]$
750
$0.0535^{\star * *}$
$[3.041]$
1,857
-0.0689 **
$[-2.077]$

$[-2.077]$

\subsection{8}

[1.180]

690

$0.0727^{\text {*** }}$

[3.456]

1,917

$-0.0280$

[-0.669]

0.0096

[0.217]

545

$0.0801^{\text {** }}$

[3.969]

2,062

$-0.0705$

[-1.554]
0.0227

[0.490]

599

$0.1103^{\text {** }}$

[4.488]

2,008

$-0.0876^{\star}$

[-1.695]

$-0.0155$

[-0.272]

433

$0.1112^{\star \star \star}$

[4.749]

2,174

$-0.1268^{\star \star}$

[-2.172]

\begin{tabular}{|c|c|c|c|}
\hline 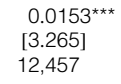 & $\begin{array}{l}0.0245^{\star \star \star} \\
{[2.905]} \\
9,951\end{array}$ & $\begin{array}{l}0.0267^{* *} \\
{[2.380]} \\
8,672\end{array}$ & $\begin{array}{c}0.001 \\
{[0.076]} \\
7,984\end{array}$ \\
\hline $\begin{array}{c}-0.0121^{\star} \\
{[-1.732]} \\
4,188\end{array}$ & $\begin{array}{c}0.0233^{\star *} \\
{[2.485]} \\
6,694\end{array}$ & $\begin{array}{l}0.0616^{\star * *} \\
{[5.629]} \\
7,973\end{array}$ & $\begin{array}{l}0.1046^{\star \star \star} \\
{[8.105]} \\
8,661\end{array}$ \\
\hline $\begin{array}{l}0.0274^{\star \star \star} \\
{[3.030]}\end{array}$ & $\begin{array}{c}0.0012 \\
{[0.096]}\end{array}$ & $\begin{array}{l}-0.0349^{* *} \\
{[-2.217]}\end{array}$ & $\begin{array}{l}-0.1036^{\star \star \star} \\
{[-5.512]}\end{array}$ \\
\hline $\begin{array}{c}-0.0024 \\
{[-0.503]} \\
11,478\end{array}$ & $\begin{array}{c}-0.0169^{*} \\
{[-1.810]} \\
8,250\end{array}$ & $\begin{array}{c}-0.0373^{\star \star \star} \\
{[-2.825]} \\
6,577\end{array}$ & $\begin{array}{c}-0.0830^{\star \star \star} \\
{[-4.935]} \\
5,650\end{array}$ \\
\hline $\begin{array}{c}0.0326^{\star \star \star} \\
{[4.880]} \\
5,167\end{array}$ & $\begin{array}{l}0.0642^{\star \star \star ~} \\
{[7.587]} \\
8,395\end{array}$ & $\begin{array}{l}0.0962^{\star \star \star} \\
{[9.923]} \\
10,068\end{array}$ & $\begin{array}{c}0.1258^{\star \star \star} \\
{[11.200]} \\
10,995\end{array}$ \\
\hline $\begin{array}{l}-0.0350 \text { *ᄎ* } \\
{[-4.120]}\end{array}$ & $\begin{array}{l}-0.0810^{\star * *} \\
{[-6.444]}\end{array}$ & $\begin{array}{l}-0.1334^{* * *} \\
{[-8.316]}\end{array}$ & $\begin{array}{c}-0.2089^{\star \star \star} \\
{[-10.561]}\end{array}$ \\
\hline
\end{tabular}

TABLE B3

\section{Long-Run Abnormal Returns Including and Excluding Subsequent Events for Value Firms}

Appendix Table B3 presents long-run abnormal returns for OMR program authorization announcements made by value firms, defined as firms in the lowest market-to-book quintile at the time of the authorization. Where indicated, abnormal returns are calculated excluding firm-months during which a subsequent repurchase authorization is announced and months during which a takeover attempt is announced. Monthly abnormal returns $(\alpha)$ are estimated from Fama-French (1993) 3-factor calendar-time portfolio regressions: $R_{t}-R_{f, t}=\alpha_{1}+\beta_{1}\left(R_{m k t, t}-R_{f, t}\right)+\beta_{2} S M B_{t}+\beta_{3} H M L_{t}$, where $R_{t}$ is the return on an equal-weighted portfolio of stocks at time $t . R_{f, t}$ and $R_{m k t, t}$ are the risk-free rate and the return of the market at time $t . S M B_{t}$ and $H M L_{t}$ are the monthly returns on the Fama-French size and book-to-market factors in month $t$. The intercept term $(\alpha)$ of the regression represents the average monthly excess return in the event period. $t$-statistics are reported in square brackets. ${ }^{*},{ }^{\star *}$, and ${ }^{* * *}$ indicate significance at the $10 \%, 5 \%$, and $1 \%$ levels, respectively.

\begin{tabular}{|c|c|c|c|c|}
\hline Excluded Months & 12 Months & 24 Months & 36 Months & 48 Months \\
\hline (1) None & $\begin{array}{l}0.4717^{\star \star \star} \\
{[3.366]}\end{array}$ & $\begin{array}{l}0.3911^{\star \star \star} \\
{[3.109]}\end{array}$ & $\begin{array}{l}0.3152^{\star * *} \\
{[2.614]}\end{array}$ & $\begin{array}{l}0.2996 \text { ** } \\
{[2.555]}\end{array}$ \\
\hline (2) Subsequent repurchase authorizations & $\begin{array}{l}0.4410^{\star \star \star} \\
{[3.107]}\end{array}$ & $\begin{array}{l}0.3576^{\star \star \star} \\
{[2.825]}\end{array}$ & $\begin{array}{l}0.2880^{\star *} \\
{[2.373]}\end{array}$ & $\begin{array}{l}0.2777^{\star \star} \\
{[2.359]}\end{array}$ \\
\hline (3) Subsequent authorizations and takeovers & $\begin{array}{l}0.3116^{\star \star} \\
{[2.253]}\end{array}$ & $\begin{array}{c}0.2237^{\star} \\
{[1.818]}\end{array}$ & $\begin{array}{c}0.1600 \\
{[1.344]}\end{array}$ & $\begin{array}{c}0.1469 \\
{[1.263]}\end{array}$ \\
\hline
\end{tabular}




\section{TABLE B4}

\section{Buy-and-Hold Abnormal Returns Analysis for Value Firms}

Panel A of Appendix Table B4 presents average abnormal buy-and-hold returns for value firms, defined as firms in the lowest market-to-book quintile at the time of the authorization. Abnormal buy-and-hold returns are calculated as the buyand-hold return on the OMR firm minus the average buy-and-hold return of 5 size and book-to-market matched control firms. Panel B reports the results of regressions explaining abnormal buy-and-hold returns for value firms. Number of repurchase (takeover) announcements is the number of subsequent OMR (takeover) announcements that occur during the returns calculation period. $t$-statistics are reported in square brackets and robust standard errors are clustered by firm. ${ }^{*},{ }^{* *}$, and ${ }^{* * *}$ indicate significance at the $10 \%, 5 \%$, and $1 \%$ levels, respectively.

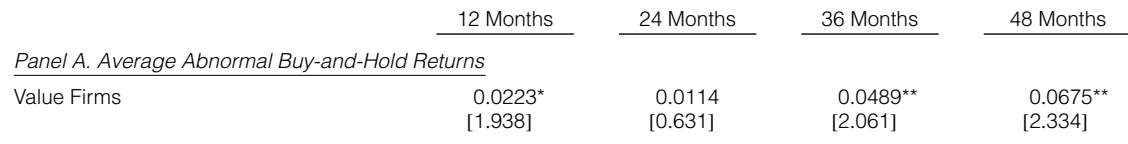

Panel B. Regressions Explaining Buy-and-Hold Returns for Sample of Authorizations by Value Firms

\begin{tabular}{|c|c|c|c|c|}
\hline Number of repurchase announcements & $\begin{array}{c}-0.007 \\
{[-0.334]}\end{array}$ & $\begin{array}{c}0.067^{\star} \\
{[1.712]}\end{array}$ & $\begin{array}{c}0.089^{*} \\
{[1.720]}\end{array}$ & $\begin{array}{c}0.131^{\star *} \\
{[2.098]}\end{array}$ \\
\hline Number of takeover announcements & $\begin{array}{l}0.178^{\star \star \star} \\
{[4.300]}\end{array}$ & $\begin{array}{l}0.135^{\star \star \star} \\
{[3.201]}\end{array}$ & $\begin{array}{c}0.107^{* *} \\
{[2.426]}\end{array}$ & $\begin{array}{c}0.137^{* *} \\
{[2.500]}\end{array}$ \\
\hline Constant & $\begin{array}{c}0.009 \\
{[0.681]}\end{array}$ & $\begin{array}{c}-0.040 \\
{[-1.636]}\end{array}$ & $\begin{array}{c}-0.028 \\
{[-0.770]}\end{array}$ & $\begin{array}{c}-0.065 \\
{[-1.339]}\end{array}$ \\
\hline $\begin{array}{l}\text { No. of obs. } \\
\text { Adj. } R^{2}\end{array}$ & $\begin{array}{l}2,434 \\
0.009\end{array}$ & $\begin{array}{l}2,434 \\
0.007\end{array}$ & $\begin{array}{l}2,434 \\
0.007\end{array}$ & $\begin{array}{l}2,434 \\
0.013\end{array}$ \\
\hline
\end{tabular}

\section{TABLE B5}

Takeover Probability Regression

Appendix Table B5 presents estimates from a logit model predicting takeovers. The sample covers all firms with the available Center for Research in Security Prices (CRSP) and Compustat data for the years 1981-2009. The dependent variable is a dummy variable equal to 1 if a takeover is announced for the firm during the year, and 0 otherwise. PPE is property, plant and equipment scaled by assets. $\log (\mathrm{Cash})$ is the log of cash holdings. Blockholder is a dummy variable equal to 1 if an institutional investor holds more than $5 \%$ of the company's stock, and 0 otherwise. $\log (\mathrm{MVE})$ is the log of the market value of equity. Leverage is long-term debt plus debt in current liabilities divided by the sum of long-term debt, debt in current liabilities, and the market value of equity. Operating cash flow is the ratio of operating income before depreciation to total assets. Sales growth is the natural logarithm of the ratio of sales to prior year sales, and Industry takeover dummy is equal to 1 if there was a takeover announcement for a firm in the same Fama-French 48 industry during the year, and 0 otherwise. The independent variables are lagged 1 year, and the Compustat variables are industry adjusted based on Fama-French 48 industries. $t$-statistics are reported in square brackets. ${ }^{*}{ }^{* *}$, and ${ }^{* * *}$ indicate significance at the $10 \%, 5 \%$, and $1 \%$ levels, respectively.

\begin{tabular}{|c|c|}
\hline Dependent Variable & $\begin{array}{c}\text { Takeover Indicator } \\
1 \\
\end{array}$ \\
\hline Market-to-book & $\begin{array}{l}-0.0576^{\star \star *} \\
{[-3.416]}\end{array}$ \\
\hline PPE & $\begin{array}{r}0.0260 \\
{[0.854]}\end{array}$ \\
\hline In(Cash) & $\begin{array}{r}0.0083 \\
{[1.028]}\end{array}$ \\
\hline Blockholder & $\begin{array}{l}0.9164^{* * *} \\
{[30.512]}\end{array}$ \\
\hline $\ln (\mathrm{MVE})$ & $\begin{array}{l}-0.0715^{\star \star \star} \\
{[-10.337]}\end{array}$ \\
\hline Leverage & $\begin{array}{l}0.6041^{\star \star \star} \\
{[8.934]}\end{array}$ \\
\hline Operating cash flow & $\begin{array}{r}0.0037 \\
{[0.079]}\end{array}$ \\
\hline Sales growth & $\begin{array}{r}-0.0000 \\
{[-1.089]}\end{array}$ \\
\hline Industry takeover dummy & $\begin{array}{l}0.2371^{*} \\
{[1.801]}\end{array}$ \\
\hline Constant & $\begin{array}{l}-3.4182^{\star \star \star} \\
{[-21.312]}\end{array}$ \\
\hline Year dummies & Yes \\
\hline $\begin{array}{l}\text { No. of obs. } \\
\text { Pseudo- } R^{2}\end{array}$ & $\begin{array}{c}116,911 \\
0.0524\end{array}$ \\
\hline
\end{tabular}




\section{References}

Bagwell, L. S., and J. B. Shoven. "Cash Distributions to Shareholders.” Journal of Economic Perspectives, 3 (1989), 129-140.

Bargeron, L.; A. Bonaime; and S. Thomas. "The Information Content of Repurchase Status Updates." Working Paper, University of Pittsburgh (2016).

Banyi, M. L.; E. A. Dyl; and K. E. Kahle. "Errors in Estimating Share Repurchases." Journal of Corporate Finance, 14 (2008), 460-474.

Betton, S.; E. Eckbo; and K. S. Thorburn. "Corporate Takeovers.” In Handbook of Corporate Finance: Empirical Corporate Finance, Handbooks in Finance Series, Vol. II, B. E. Eckbo, ed. Amsterdam: Elsevier (2008), 291-430.

Billett, M., and H. Xue. "The Takeover Deterrent Effect of Open Market Share Repurchases.” Journal of Finance, 62 (2007), 1827-1850.

Carhart, M. "On Persistence in Mutual Fund Performance.” Journal of Finance, 52 (1997), 57-82.

Chan, K.; D. Ikenberry; and I. Lee. "Economic Sources of Gain in Stock Repurchases." Journal of Financial and Quantitative Analysis, 39 (2004), 461-479.

Chen, S., and Y. Wang. "Financial Constraints and Share Repurchases." Journal of Financial Economics, 105 (2012), 311-331.

Comment, R., and G. A. Jarrell. "The Relative Signaling Power of Dutch-Auction and FixedPrice Self-Tender Offers and Open-Market Share Repurchases.” Journal of Finance, 46 (1991), 1243-1271.

Cremers, K. J. M.; V. B. Nair; and K. John. "Takeovers and the Cross-Section of Returns.” Review of Financial Studies, 22 (2009), 1409-1445.

Cusatis, P. J.; J. A. Miles; and J. R. Woolridge. "Restructuring through Spinoffs." Journal of Financial Economics, 33 (1993), 293-311.

Fama, E. F. "Market Efficiency, Long-Term Returns, and Behavioral Finance." Journal of Financial Economics, 49 (1998), 283-306.

Fama, E. F., and K. R. French. "Common Risk Factors in the Returns on Stocks and Bonds." Journal of Financial Economics, 33 (1993), 3-56.

Grullon, G., and R. Michaely. "The Information Content of Share Repurchase Programs." Journal of Finance, 59 (2004), 651-680.

Ibbotson, R. G. "Price Performance of Common Stock New Issues." Journal of Financial Economics, 2 (1975), 235-272.

Ikenberry, D.; J. Lakonishok; and T. Vermaelen. "Market Underreactions to Open Market Share Repurchases.” Journal of Financial Economics, 39 (1995), 181-208.

Ikenberry, D.; J. Lakonishok; and T. Vermaelen. "Stock Repurchases in Canada: Performance and Strategic Trading.” Journal of Finance, 55 (2000), 2373-2397.

Lin, J. C.; C. P. Stephens; and Y. L. Wu. "Limited Attention, Share Repurchases, and Takeover Risk." Journal of Banking and Finance, 42 (2014), 283-301.

Manconi, A.; U. Peyer; and T. Vermaelen. "Buybacks around the World." Working Paper, INSEAD (2012).

Mitchell, M. L., and E. Stafford. "Managerial Decisions and Long-Term Stock Price Performance." Journal of Business, 73 (2000), 287-329.

Mulherin, J. H., and A. B. Poulsen. "Proxy Contests and Corporate Change: Implications for Shareholder Wealth." Journal of Financial Economics, 47 (1998), 279-313.

Peyer, U., and T. Vermaelen. "The Nature and Persistence of Buyback Anomalies." Review of Financial Studies, 22 (2009), 1693-1745.

Stephens, C., and M. Weisbach. "Actual Share Reacquisitions in Open-Market Repurchase Programs." Journal of Finance, 53 (1998), 313-333.

Vermaelen, T. “Common Stock Repurchases and Market Signaling: An Empirical Study.” Journal of Financial Economics, 9 (1981), 139-183. 